\title{
Heme oxygenase, inflammation, and fibrosis: the good, the bad, and the ugly?
}

\author{
Ditte M. S. Lundvig ${ }^{1}$, Stephan Immenschuh ${ }^{2}{ }^{*}$ and Frank A. D. T. G. Wagener ${ }^{1 *}$ \\ ${ }^{1}$ Department of Orthodontics and Craniofacial Biology, Nijmegen Centre for Molecular Life Sciences, Radboud University Nijmegen Medical Centre, Nijmegen, \\ Netherlands \\ 2 Institute for Transfusion Medicine, Hannover Medical School, Hannover, Germany
}

\section{Edited by:}

Mahin D. Maines, University of

Rochester School of Medicine, USA

Reviewed by:

Roberto Motterlini, Institut National de la Santé et de la Recherche

Médicale, France

Rene Schmidt, Freiburg University

Medical Center, Germany

\section{*Correspondence:}

Stephan Immenschuh, Institute for

Transfusion Medicine, Hannover

Medical School, Carl Neuberg-Street

1, 30625 Hannover, Germany.

e-mail:immenschuh.stephan@

mh-hannover.de;

Frank A. D. T. G. Wagener,

Department of Orthodontics and

Craniofacial Biology, Nijmegen Centre

for Molecular Life Sciences, Radboud

University Nijmegen Medical Centre,

PO Box 9101, 6500 HB Nijmegen,

Netherlands.

e-mail: f.wagener@dent.umcn.nl
Upon injury, prolonged inflammation and oxidative stress may cause pathological wound healing and fibrosis, leading to formation of excessive scar tissue. Fibrogenesis can occur in most organs and tissues and may ultimately lead to organ dysfunction and failure. The underlying mechanisms of pathological wound healing still remain unclear, and are considered to be multifactorial, but so far, no efficient anti-fibrotic therapies exist. Extra- and intracellular levels of free heme may be increased in a variety of pathological conditions due to release from hemoproteins. Free heme possesses pro-inflammatory and oxidative properties, and may act as a danger signal. Effects of free heme may be counteracted by heme-binding proteins or by heme degradation. Heme is degraded by heme oxygenase $(\mathrm{HO})$ that exists as two isoforms: inducible $\mathrm{HO}-1$ and constitutively expressed $\mathrm{HO}-2$. $\mathrm{HO}$ generates the effector molecules biliverdin/bilirubin, carbon monoxide, and free iron/ferritin. $\mathrm{HO}$ deficiency in mouse and man leads to exaggerated inflammation following mild insults, and accumulating epidemiological and preclinical studies support the widely recognized notion of the cytoprotective, anti-oxidative, and anti-inflammatory effects of the activity of the $\mathrm{HO}$ system and its effector molecules. In this review, we address the potential effects of targeted $\mathrm{HO}-1$ induction or administration of $\mathrm{HO}$-effector molecules as therapeutic targets in fibrotic conditions to counteract inflammatory and oxidative insults. This is exemplified by various clinically relevant conditions, such as hypertrophic scarring, chronic inflammatory liver disease, chronic pancreatitis, and chronic graft rejection in transplantation.

Keywords: heme oxygenase, heme, HO-effector molecules, fibrosis, therapy

\section{INTRODUCTION}

Tissue injury can occur after physical, chemical, or infectious insults, such as burns, trauma, and toxins. Wound healing is a dynamic and complex process involving the coordinated action of different cell types. The quality of the wound healing process is dependent on different factors, including the severity of the insult and the inflammatory and redox status of the wound. Pathological wound healing can lead to two extreme cases: chronic, non-healing wounds or fibrosis, which ultimately may lead to excessive scarring. Both types of complications related to pathological wound healing have major impact on patient quality of life in terms of aesthetical and functional problems.

Numerous clinical and experimental observations have demonstrated that prolonged inflammation and oxidative stress may cause pathological wound healing and the development of fibrosis. However, the underlying mechanisms still remain largely unclear. Inflammation is a complex response of the innate immune system in vascularized tissues initiated to protect the organism against invading pathogens as well as to restore tissue homeostasis at the wound site.

\section{WOUND HEALING AND FIBROSIS - WHEN GOOD TURNS BAD}

The primary goal of tissue repair is to restore tissue integrity and homeostasis. Hereto, wounding initiates a complex cascade of events to stop blood loss, to eliminate invading pathogens, and, ultimately, to promote tissue integrity and homeostasis (Chettibi et al., 1999; Hunt et al., 2000).

Wound healing occurs in three distinct, but overlapping phases: (1) inflammation, (2) regeneration, and (3) remodeling, and involves a well-coordinated sequence of cellular responses.

The inflammatory phase is preceded by blood clot formation and coagulation to stop blood loss and to reduce pathogen invasion. This fibrin-containing clot also serves as an early provisional extracellular matrix (ECM) to provide structural support for cellular attachment and proliferation. Coagulation also triggers the production of pro-inflammatory agents, and activation of the complement system. This leads to increased blood vessel permeability, chemokine expression, vascular adhesion molecule expression, and recruitment of immune cells. At the wound site, granulocytes and macrophages are pivotal for the innate immune systemmediated elimination of invading pathogens through the generation of reactive oxygen species (ROS; Fialkow et al., 2007), and the production of pro-inflammatory chemokines and cytokines (Ryan et al., 2004).

The temporal and spatial pattern of inflammation resolution is crucial for proper wound healing and is characterized by reduced levels of pro-inflammatory adhesion molecules and cytokines and a decreasing number of inflammatory cells at the site of injury. 
This is followed by the initiation of the regenerative phase that mediates re-epithelialization, neovascularization, and wound closure. In particular, fibroblasts produce and deposit ECM components to substitute the provisional matrix. Also, recruited keratinocytes and endothelial cells are crucial to this process.

When the wound area is fully re-epithelialized, remodeling takes over from regeneration. Fibroblasts differentiate into myofibroblasts causing wound contraction and ECM reorganization by synthesis and deposition of ECM components and by providing matrix metalloproteinases (MMPs) and tissue inhibitors of MMPs (TIMPs), which ultimately leads to wound closure. At the end of this phase, myofibroblasts present in the granulation tissue disappear by apoptosis, producing a rather acellular scar. It is important to realize that scar formation is a natural part of the wound healing process, as normal scar tissue, which mainly consists of connective tissue, represents a stable restoration of the skin (for a recent review, see Guo and Dipietro, 2010).

Prolonged inflammatory conditions accompanied by oxidative stress may interfere with the normal wound healing process, leading to an extended presence of myofibroblasts and excessive scar formation, a process known as fibrosis. Fibrosis is not only restricted to dermal wound healing, but also occurs in palatal tissue, lungs, heart, liver, intestine, and joints, and causes major medical problems ranging from disfigurement to progressive disability and even death.

Despite the fact that disorders that are associated with fibrosis account for up to $45 \%$ of deaths in the developed world, no successful anti-fibrotic therapies exist (Wynn, 2008).

Extensive research has shown that the heme-heme oxygenase (HO) system is closely involved in the regulation of various (patho)physiological processes, in particular in cellular adaptation to oxidative stress, and the anti-inflammatory response.

In this review, we address the role of heme, HO- 1 and HOeffector molecules in inflammation and fibrosis with an emphasis on hypertrophic scarring, chronic inflammatory liver disease, chronic pancreatitis, and transplantation complications.

\section{INFLAMMATION AND SCARRING - WHEN BAD TURNS UGLY}

A prolonged inflammatory phase is considered a major cause of fibrosis and excessive scar formation. A clear link between inflammation and fibrosis has been revealed through embryonic studies. Mammalian embryos heal without scar formation, if wound healing occurs without influx of inflammatory cells (Ashcroft et al., 1999), indicating that inflammatory cell recruitment to the wound site is a prerequisite for scar formation. Wound healing studies in different knockout and transgenic mouse models (Fathke et al., 2004; Duffield et al., 2005; Oakley et al., 2005; Tabibiazar et al., 2006; Saito et al., 2008; Goren et al., 2009), athymic mice (Gawronska-Kozak et al., 2006), and in vivo antisense knockdown studies (Mori et al., 2006, 2008; Mathew et al., 2007) further support this notion. Also, an overwhelming amount of data have shown that inflammatory cells emigrating from blood, such as granulocytes, macrophages, and helper T cells, provide signals that promote granulation and fibrosis, including ROS, ECM deposition, and chemokines and cytokines (reviewed in Martin and Leibovich, 2005).
Clinical data demonstrate elevated inflammatory profiles in patients with pathological scarring (Harty et al., 2003; Martin and Leibovich, 2005). Also, chronic wounds demonstrate impaired resolution of the inflammatory phase, and thus remain in a chronic inflammatory state (Loots et al., 1998). Time is a critical factor for abnormal scar formation, as long-lasting wound healing significantly increases the risk of hypertrophic or excessive scarring (Deitch et al., 1983).

The continuous presence of inflammatory mediators results in increased secretion of growth factors, extending the proliferative phase via the prolonged presence of myofibroblasts (Singer and Clark, 1999). This in turn causes excessive deposition of ECM components, exaggerating the outcome of the proliferative phase and contributing to hypertrophic scarring or fibrosis (Aarabi et al., 2007). Thus, the inflammatory cell-derived ROS generated during the early inflammatory phase must be tightly controlled by cellular anti-oxidative and anti-inflammatory systems, as impaired ROS clearance exacerbates wound healing (Frantz et al., 1993; Steiling et al., 1999).

The unifying hallmark of fibrotic disorders is abnormal and excessive deposition of ECM components. As exemplified in the following sections, the broad range of affected organs, the progressive and often irreversible nature of fibrosis, and the large number of affected patients combined with ineffective treatment poses a challenge to the development of novel therapeutic approaches toward limiting fibrosis.

\section{HYPERTROPHIC SCARRING}

The skin is the organ with the largest surface area in the body, functioning as a barrier against the external milieu, and is important in protecting the body against pathogens and dehydration. Other functions include temperature regulation, tactile sensation, and vitamin D synthesis.

Upon cutaneous injury, dermal wound healing is crucial for restoration of the damaged skin barrier. In most cases, wound healing will result in the formation of a visible scar. However, prolonged inflammation and high levels of oxidative stress (e.g., due to infections) may result in excessive deposition of predominantly collagen I (Sidgwick and Bayat, 2012), leading to fibrosis and excessive scarring that in skin is manifested as a hypertrophic or a keloid scar. Both keloids and hypertrophic scars are characterized by excessive collagen deposition and are discolored with a rough, stiff appearance, but whereas hypertrophic scars are confined to the original wound area, keloids overgrow these boundaries. Hypertrophic scars may occur in persons of any age and at any site, whereas keloids develop with higher risk in certain ethnic groups (Brissett and Sherris, 2001). Almost all abnormal scars are associated with prolonged inflammation caused by foreign body reaction, bacterial infections, tattoos, burns, injections, bites, cuts, vaccination, trauma, surgery, or infections. Importantly, immunological alterations have been reported in hypertrophic scars, including abnormal growth factor and cytokine levels (van der Veer et al., 2009).

Often patients report itching and pain as major issues besides the aesthetical and functional problems (Bock et al., 2006). These complications may require surgical corrections, which may then lead to further scarring complications. 


\section{FIBROSIS IN CHRONIC INFLAMMATORY LIVER DISEASE AND CHRONIC PANCREATITIS}

Liver and pancreas are two major abdominal organs which have specific exocrine and endocrine functions within the gastrointestinal tract and in control of the body's metabolic homeostasis.

The liver is not only a major regulator of systemic metabolism but also has key functions in detoxification of endogenous and exogenous toxins. Hepatic fibrosis is mainly caused by chronic hepatitis $\mathrm{B}$ and $\mathrm{C}$, alcoholic liver disease, and fatty liver disease/non-alcoholic steatohepatitis (extensively reviewed in Hernandez-Gea and Friedman, 2011). Albeit from different origins, these disorders have similar early pro-inflammatory features, which can progress into hepatic fibrosis and ultimately into end stage liver cirrhosis. Hepatic fibrosis can be regarded as a result of the hepatic wound healing response to repeated injury. If hepatic injury sustains, failure of liver regeneration occurs and results in fibrosis, in which activated hepatic stellate cells (HSCs) play a key role via excessive production of ECM components. More specifically, HSC activation is the result of a complex sequence of events such as secretion of pro-inflammatory cytokines by other hepatic cells such as liver tissue macrophages (Kupffer cells). Ultimately, hepatic fibrosis and cirrhosis lead to a replacement of healthy hepatic tissue with scars and regenerative nodules, causing loss of liver function.

The pancreas is a major gland organ and has crucial exocrine functions in the gastrointestinal digestive tract. In addition, it is a major endocrine organ and produces the glucose-regulating peptide hormones insulin and glucagon. Chronic pancreatitis is a progressive inflammatory disease (Witt et al., 2007), which is most commonly caused by chronic alcoholism or is of idiopathic origin. Similar to the liver, pancreatic stellate cells (PSCs) play a key role in pancreatic fibrogenesis (Omary et al., 2007). Normally, PSCs regulate the synthesis and degradation of ECM proteins and, thereby, the maintenance of the healthy tissue architecture. Upon pancreatic injury, PSCs differentiate into an activated phenotype which is secreting excessive amounts of ECM components and leads to the formation of fibrotic tissue (Omary et al., 2007). Persistent inflammation of the pancreas causes permanent structural deterioration with tissue fibrosis and ductal obstruction, and subsequently irreversible, declined exocrine and endocrine function (pancreatic insufficiency).

\section{FIBROSIS ASSOCIATED WITH GRAFT REJECTION}

During transplantation, cells, tissues, or organs are transferred between organisms from one individual to another or from one site to another in the same individual to correct the loss or dysfunction of an organ (e.g., kidney, liver, skin). A major problem in transplantation biology is the immunological barrier between donor and recipient, which may cause graft rejection. Based on clinical and pathological criteria, graft rejection has been classified into three major forms: hyperacute, acute, and chronic graft rejection (Azimzadeh et al., 2011). Hyperacute rejection starts within minutes of transplantation and exhibits thrombosis of graft vessels and ischemic necrosis due to circulating recipient antibodies, and organ failure occurs hours after transplantation. Moreover, acute graft rejection generally occurs within days or weeks after organ transplantation and leads to graft failure within the first year post-transplantation. This form of rejection has been primarily linked to a T cell-mediated reaction of graft destruction. Finally, chronic transplant rejection (CTR) is less well defined and results from multifactorial, pathological events, involving both immunological and non-immunological factors. Immune cells such as $\mathrm{T}$ cells and macrophages, chemokines, pro-inflammatory cytokines, and allo-antibodies have all been linked to the initiation and progression of the rejection process (Cornell et al., 2008; Ashoor and Najafian, 2012). Organs subjected to CTR generally display fibrotic scarring and vascular damage due to transplant vasculopathy (TV), which has similar features to atherosclerosis (Mitchell, 2009; Racusen and Regele, 2010).

Together, impaired resolution of inflammation and/or elevated levels of ROS may facilitate fibrosis and scar formation. It is now commonly accepted that the heme-HO system is a key player in the control of the inflammation and oxidative stress (Keyse and Tyrrell, 1989; Willis et al., 1996; Rushworth and O'Connell, 2004; Pae et al., 2008).

\section{THE HEME-HO SYSTEM}

The microsomal enzyme heme oxygenase (HO) catalyzes the oxidative degradation of free heme, and generates carbon monoxide (CO), ferrous iron $\left(\mathrm{Fe}^{2+}\right)$, and biliverdin (Tenhunen et al., 1968; Maines, 1988). Two genetically distinct HO isoforms exist: an inducible form, HO-1, and the constitutively expressed HO-2 (Immenschuh and Ramadori, 2000). Accumulating data demonstrate that the $\mathrm{HO}$ enzymes execute anti-inflammatory, antiapoptotic, and anti-proliferative functions through the effector molecules generated by heme catabolism (reviewed in Willis et al., 1996; Abraham and Kappas, 2008). Biliverdin is almost instantaneously converted into bilirubin by biliverdin reductase, and the free iron is rapidly scavenged by co-induced ferritin (Wagener et al., 2003a). CO, $\mathrm{Fe}^{2+}$ /ferritin, and biliverdin/bilirubin affect different biological processes (Abraham and Kappas, 2008), including resolution of inflammation (Willoughby et al., 2000); however, the executed effects depend on the generated amounts and the microenvironment (Wagener et al., 2003b).

\section{HEME AS A MOLECULAR SWITCH}

Heme (iron protoporphyrin IX) is composed of an iron atom conjugated to a porphyrin group. Heme is synthesized by every mammalian cell, and enables in physiological concentrations a wide range of essential biological functions, by acting as the prosthetic group for hemoproteins (hemoglobin, cyclooxygenases, peroxidases) and cellular signaling (reviewed in Wagener et al., 2003b).

However, upon injury, free heme is released from hemoproteins, causing severe tissue damage (Nath et al., 1995; Balla et al., 2000; Ryter and Tyrrell, 2000; Jeney et al., 2002), predominantly by generating ROS through the Fenton reaction (Halliwell and Gutteridge, 1984) and oxidative modifications of proteins (Nath et al., 1995; Jeney et al., 2002). Also, local accumulation of high levels of free heme, e.g., in blood clots, or atherosclerotic lesions (Hasan and Schafer, 2008), overwhelms cellular detoxification systems by prolonged oxidative stress, which may cause ROS-dependent oxidation of lipids, proteins, and DNA, subsequently damaging cells and tissues (Balla et al., 1991, 1993; Jeney et al., 2002). 
Furthermore, accumulating evidence shows that heme besides being a pro-oxidant in high concentration also possesses proinflammatory properties, because heme increases the expression of vascular adhesion molecules ICAM-1, VCAM-1, and E-selectin (Wagener et al., 1997, 1999, 2001a; Tolosano et al., 2002; Belcher et al., 2006), upregulates vascular permeability (Wagener et al., 2001b), promotes leukocyte recruitment (Wagener et al., 2001b; Porto et al., 2007), and induces the release of pro-inflammatory cytokines (Natarajan et al., 2007; Cosgrove et al., 2011; Hao et al., 2011). Administration of large amounts of heme has been demonstrated to not only result in oxidative and inflammatory stress (Wagener et al., 2001a,b; Tolosano et al., 2002), but also to exacerbate different disease settings (Pamplona et al., 2007; Seixas et al., 2009; Larsen et al., 2010). Together, this heme-induced injury has been associated with pathological manifestations of different conditions, e.g., malaria (Pamplona et al., 2007). Interestingly, increased heme levels have also been associated with fibrosis formation (Tolosano et al., 2002; Kovtunovych et al., 2010).

Furthermore, independent studies have supported a role for heme in wound healing. In moderate concentrations, heme stimulates vasoconstriction, pro-coagulation, complement activation, platelet aggregation, and cell differentiation (Nakajima et al., 1999). Also, low concentrations of free heme down-regulates the levels of pro-inflammatory cytokines, contributing to the resolution of inflammation, likely by inducing $\mathrm{HO}-1$ expression ( $\mathrm{Ma}$ et al., 2007; Cambos et al., 2010; Cambos and Scorza, 2011).

Consequently, heme can be considered as a molecular switch, since different concentrations of free heme generate different cellular responses (Wagener et al., 2003a). In small amounts, it provides essential cellular functions and cytoprotection via $\mathrm{HO}-1$ induction, whereas in high concentrations, free heme can cause severe tissue injury. It is thus of importance to control the levels of free heme at sites of injury.

\section{THE HEME-HO SYSTEM AND INFLAMMATION - FRIENDS OR FOE?}

The dose-dependency of the effects mediated by free heme underscores the importance of proper control of the cellular levels hereof by the HO system.

High levels of free heme in the vascular system have been suggested to be involved in the initiation and progression of atherosclerosis, a chronic inflammatory vascular disease with fibrotic plaque pathology (Hasan and Schafer, 2008). Hemeinduced oxidative stress induces expression of immediate early gene early growth response (Egr)-1 protein (Hasan and Schafer, 2008) that has been directly linked to vascular pathologies (McCaffrey et al., 2000; Blaschke et al., 2004). Importantly, this induction is inhibited by CO (Hasan and Schafer, 2008), underscoring the importance of the heme-HO feedback loop as a mechanism to counteract pathological levels of free heme. Heme also triggers vascular pro-inflammatory processes by promoting foam cell formation through oxidative modification of low-density lipoprotein (LDL) and apolipoprotein B100, which are major risk factors for the development of atherosclerosis (Tsimikas and Miller, 2011).

In contrast, free heme is an inducer of the expression of stress-sensitive genes, including HO-1, ferritin, Hsp70 as well as chemokines, and adhesion molecules (Theodorakis et al., 1989; Wagener et al., 1997; Kanakiriya et al., 2003; Iwasaki et al., 2006).
Also, the local release of large amounts of free heme upon injury induces inflammatory processes, suggesting that heme acts as a danger signal (Wagener et al., 2003a; Figueiredo et al., 2007).

Furthermore, the induction of HO-1 by increased levels of heme at the site of injury also functions as a feedback system by improving the anti-inflammatory response, as $\mathrm{HO}$ activity counteracts a diverse range of cellular stresses (Abraham et al., 1988).

Recently, we and others have demonstrated a clear link between $\mathrm{HO}$ activity and diverse (pathological) cellular processes, as $\mathrm{HO}$ activity has been shown to be cytoprotective and anti-apoptotic as well as to reduce oxidative stress and inflammation in a multitude of different cellular and rodent models (Willis et al., 1996; Soares et al., 1998; Brouard et al., 2000; Rucker et al., 2001; Wagener et al., 2003a, 2010; Ryter and Choi, 2009; Gozzelino et al., 2010). These effects are mediated through the actions of the effector molecules generated by HO activity (Abraham and Kappas, 2008), as biliverdin and bilirubin possess strong anti-oxidant properties and $\mathrm{CO}$ is implicated in different signaling cascades and vasodilatation (Siow et al., 1999).

Moreover, overexpression of HO-1 counteracts the cytotoxic, pro-oxidative and pro-inflammatory effects caused by heme via down-regulating inflammatory adhesion molecules and abrogating tissue influx of leukocytes (Wagener et al., 1999, 2001b, 2003b; Rucker et al., 2001). On the contrary, inhibition of HO activity intensifies the heme-mediated oxidative and inflammatory injury in vitro and in vivo (Hayashi et al., 1999; Vachharajani et al., 2000; Rucker et al., 2001; Takahashi et al., 2007, 2009; Figure 1).

This is further exemplified by studies in HO-1 knockout mice and a patient with genetic HO-1 deficiency, in which an increased expression of vascular adhesion molecules and more severe inflammation was observed (Yachie et al., 1999; Kawashima et al., 2002; Wagener et al., 2003a; Kartikasari et al., 2009; Ferenbach et al., 2010; Radhakrishnan et al., 2011). Recent studies also

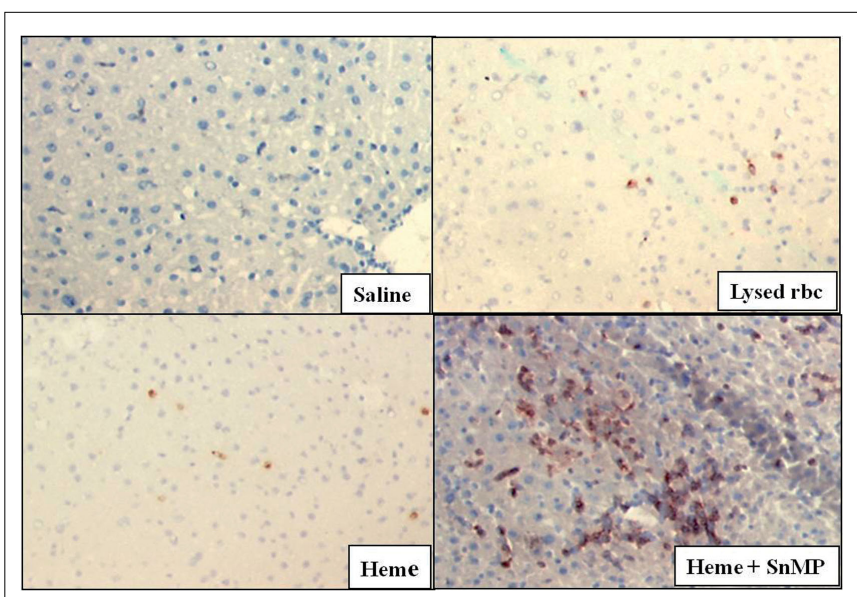

FIGURE 1 | One hour after administration of heme $(750 \mu \mathrm{M})$ or lysed red blood cells (rbc) to mouse livers, influx of leukocytes was evident by immunohistological staining. After saline administration, no leukocytes were detected. Importantly, inhibition of $\mathrm{HO}$ activity before heme exposure ( $24 \mathrm{~h}$ pretreatment, SnMP) exacerbated leukocyte influx (for more details, see Wagener et al., 2001b). 
suggest that HO-2 is important for the resolution of inflammation, as HO-2 deficient mice demonstrate slower corneal epithelial wound healing and an amplified inflammatory response (Bellner et al., 2008, 2009, 2011; Halilovic et al., 2011; Marrazzo et al., 2011).

In contrast, transgenic HO- 1 mice are better protected from oxidative stress, inflammation, and vascular dysfunction as well as fibrotic tissue formation post-infarction (Wang et al., 2010).

Also, clinical studies have suggested that swift activation of $\mathrm{HO}-$ 1 gene expression might be important to cope with cellular stresses. Several HO-1 gene promoter polymorphisms have been discovered, determining the levels of HO-1 induction in humans (Exner et al., 2004). The clinical relevance of the HO-1 promoter variability has been demonstrated in independent studies and higher HO-1 induction has been associated with lower incidence for cardiovascular and inflammatory diseases (Wagener et al., 2008; Grochot-Przeczek et al., 2012).

Thus the degradation of the pro-inflammatory and prooxidative heme molecules by $\mathrm{HO}$, the signaling actions of $\mathrm{CO}$, the anti-oxidant properties of bilirubin combined with the scavenging of the pro-oxidant free iron by ferritin may all contribute to the anti-inflammatory effects of the HO system.

By degrading heme, the HO system efficiently converts the pro-oxidative and pro-inflammatory heme molecule into antiinflammatory and anti-oxidant molecules, thereby contributing to improved wound healing. This suggests that the heme-HO system executes regulatory functions in a diverse range of cellular processes with a direct influence on a timely execution of the inflammatory phase, including resolution of inflammation, apoptosis, and proliferation. Differential protection against oxidative and pro-inflammatory insults may also explain clinical differences in fibrogenesis.

\section{PHARMACOLOGICAL REGULATION OF H0-1 AND ITS EFFECTOR MOLECULES AS THERAPEUTIC TARGETS IN INFLAMMATION AND FIBROSIS}

A rapidly growing body of experimental evidence shows that specific overexpression of HO- 1 has protective effects in inflammation and fibrosis (Bauer et al., 2008). Accordingly, pharmacological induction of HO-1 or administration of its effector molecules may be a promising therapeutic approach for the treatment of inflammatory disorders associated with fibrosis in various organs. However, to apply HO- 1 for specific therapeutic interventions a number of important issues have to be taken into consideration.

\section{ANTI-INFLAMMATORY EFFECTS OF HO-1 ARE MEDIATED IN A CELL TYPE-SPECIFIC MANNER}

$\mathrm{HO}-1$ gene expression is up-regulated in a wide range of cell types and tissues. The specific anti-inflammatory effects of HO-1, however, seem to be dependent on its coordinate up-regulation in a cell type- and cell-context-specific manner. Notably, the regulation of HO-1 expression in mononuclear/myeloid and in endothelial cells appears to be of major importance for the immunomodulatory and anti-inflammatory functions of this enzyme.

The key immunomodulatory role of HO-1 in mononuclear cells has been shown in conditional knockout mice, in which the HO-1 gene has been specifically deleted in myeloid cells. In this report, various pathological immune reactions in experimental infectious and autoimmune conditions have been demonstrated in vivo (Tzima et al., 2009). HO-1 has also been demonstrated to play a major role in the function of dendritic cells, which are a bone marrow-derived myeloid cell population involved in mediating adaptive immune responses (Remy et al., 2009; Park et al., 2010). Moreover, HO-1 appears to be of major significance for modulating inflammatory responses in endothelial cells. This has been shown in the initial reports on HO-1 knockout mice (Poss and Tonegawa, 1997) and in the first human case of genetic HO-1 deficiency (Yachie et al., 1999). In either case, the endothelium revealed specific pathological alterations, which have been ascribed to an increased endothelial sensitivity to oxidative stress. Accordingly, it was reported that genetic HO-1 deficiency exhibited phenotypic alterations of the vascular endothelium, causing accelerated formation of arterial thrombosis (True et al., 2007).

\section{REGULATION OF HO-1 GENE EXPRESSION}

To apply HO-1 induction by specific pharmacological compounds for therapeutic interventions, it is not only important to understand the physiological functions of HO-1 and its products.

It is also important to understand the specific regulatory pathways that up-regulate $\mathrm{HO}-1$. Although primarily known to be induced by oxidative stress, HO- 1 is also up-regulated by a variety of stress-independent stimuli including various well-known pharmacologic compounds (Immenschuh and Ramadori, 2000; Li et al., 2007). Regulation of HO-1 is mainly, but not exclusively governed on the transcriptional level. Accordingly, a large variety of transcription factors has been shown to be involved in $\mathrm{HO}-1$ induction. In particular, redox-dependent transcription factors such as $\mathrm{Nrf} 2$, which is a master regulator of the anti-oxidant response, activator protein-1 (AP-1) and nuclear factor (NF)- $\mathrm{B}$, but also other nuclear factors such as Egr-1, upstream regulatory factor-2 (USF-2), and specificity protein (SP)-1 have been shown to mediate HO-1 induction (Ryter et al., 2006; Paine et al., 2010). A key role in governing HO-1 expression has also been recognized for the transcriptional repressor Bach1. Bach1 is a heme-binding protein, the activity of which is primarily regulated via intracellular levels of free heme (Ogawa et al., 2001; Igarashi and Sun, 2006). As both, Bach1 and Nrf2, interact with the anti-oxidant response element (ARE), which is the major cis-acting regulatory DNA element in the HO-1 gene promoter, the interplay of these two nuclear factors appears to be of major importance for inducible $\mathrm{HO}-1$ gene expression. Whether and how Bach1 mediates the specific regulation of HO-1 if compared to other ARE-dependent stress response genes such as (NADPH):oxidoreductase-1 (NQO1) or glutathione-S-transferase (GST)-1 is a subject for currently ongoing investigations (Dhakshinamoorthy et al., 2005; MacLeod et al., 2009; Okada et al., 2010). The complexity of HO-1 gene regulation is further illustrated by the array of signaling cascades including protein kinase Cs (PKCs) and mitogen-activated protein kinases (MAPKs) that are involved in the regulation of this gene (for a review, see Paine et al., 2010). In addition, some of these pathways such as $\mathrm{p} 38$ MAPK appear to have contradictory cell-specific regulatory effects on $\mathrm{HO}-1$ gene expression (Naidu et al., 2009) indicating that HO-1 is governed by a highly complex interplay of various signaling modules. Macrophage-specific up-regulation of HO-1 gene expression in inflammation has been 
demonstrated in various experimental models (Paine et al., 2010). As an example, HO-1 in liver tissue macrophages (Kupffer cells) is up-regulated in response to the cytokine adiponectin via an IL-10 dependent pathway (Mandal et al., 2010). Moreover, macrophagespecific induction of HO-1 by various toll-like receptors (TLR) ligands, including lipopolysaccharides (LPS), requires activation of the Tec kinase Bruton's tyrosine kinase (Vijayan et al., 2011).

\section{TARGETED PHARMACOLOGICAL H0-1 INDUCTION AS THERAPY FOR INFLAMMATION AND FIBROSIS}

Numerous compounds have been shown to provide therapeutic effects via HO-1 induction. However, rather than giving an exhaustive list of compounds that may up-regulate $\mathrm{HO}-1$ for therapeutic purposes in inflammatory disorders, we refer to more specific overviews on this topic (Li et al., 2007; Abraham and Kappas, 2008; Vijayan et al., 2010).

Briefly, cobalt-protoporphyrin (CoPPIX), which has been extensively applied in various experimental models to induce HO1 , does not seem an ideal compound for targeted therapeutic HO-1 up-regulation due to possible toxicity. Interestingly, systemic administration of heme (e.g., heme arginate) to healthy individuals has been shown to increase HO-1 levels in serum (Doberer et al., 2010), and has been used in the clinics for years in the treatment of porphyria (Tenhunen and Mustajoki, 1998; Ma et al., 2011). More research is warranted to explore the potential induction of systemic $\mathrm{HO}$ activity in the human setting by heme arginate.

Natural products such as quercetin or theaflavin (Loke et al., 2008, 2010) are less toxic and may be more appropriate for potential therapeutic applications in inflammatory disorders. Interestingly, Loke et al. (2010) recently demonstrated increased expression of endothelial HO- 1 in aortic lesions and subsequently attenuation of aortic lesion formation in quercetin-fed ApoE knockout mice, underscoring the potential of targeted $\mathrm{HO}-1$ induction in clinical therapies.

Curcumin is another naturally occurring compound with a broad range of pharmacological activities, including antioxidative, anti-inflammatory, anti-carcinogenic, anti-diabetic, and anti-viral effects (Motterlini et al., 2000; McNally et al., 2007), mediating cellular protection against ROS (Barzegar and MoosaviMovahedi, 2011; Wang et al., 2012; Yin et al., 2012) by upregulating HO-1 through Nrf2 (Balogun et al., 2003). Recent studies have shown beneficial effects of curcumin in a liver injury model (Cerny et al., 2011), and curcumin treatment reduced radiation-induced lung fibrosis (Lee et al., 2010).

Moreover, macrophage-specific (Wijayanti et al., 2005) HO1 induction by defined compounds such as 4-(2-aminoethyl)benezensulfonyl fluoride (AEBSF) and endothelial cell-specific HO-1 induction by statins (Grosser et al., 2004; Lee et al., 2004), might be useful for such therapeutic applications.

Another key issue that needs attention when applying HO-1 induction for therapeutic applications deals with the question at what stage of the inflammatory phase HO-1 should be induced to afford its salutary protective effects. Importantly, HO-1 induction after the onset of an inflammatory disorder or in full-blown inflammation seems to be not effective in certain circumstances. This has been shown in an experimental model of dextran-sulfate- induced colitis, in which HO-1 failed to have anti-inflammatory effects if induced after the onset of this disease (Paul et al., 2005) or in an experimental model of acute pancreatitis (Nakamichi et al., 2005). Therefore, the time point of targeted HO-1 induction for therapeutic applications needs further attention. Alternatively, administration of $\mathrm{HO}$-effector molecules may mediate more direct anti-inflammatory effects.

\section{EXPOSURE TO HO-EFFECTOR MOLECULES CO AND BILIRUBIN: POSSIBLE AMELIORATING EFFECTS ON INFLAMMATION AND FIBROSIS}

A wide array of preclinical and epidemiological evidence suggests that the protective properties of $\mathrm{HO}$ can also be mediated via its effector molecules bilirubin, $\mathrm{CO}$, and co-induced ferritin. In inflammatory and fibrotic models both $\mathrm{CO}$ and bilirubin demonstrated significant protection (recently reviewed in Grochot-Przeczek et al., 2012).

$\mathrm{CO}$ exerts its cytoprotective effects through different mechanisms, including anti-flammatory (Neto et al., 2006; Chora et al., 2007), vasodilatory (Sammut et al., 1998), anti-coagulative (Chlopicki et al., 2006), anti-apoptotic (Wang et al., 2007), and anti-fibrotic pathways (Neto et al., 2006). CO deliverance is achieved through inhalation (Mayr et al., 2005; Moore et al., 2005), CO saturated physiological solutions (Nakao et al., 2006), and CO-releasing molecules (CO-RMs; Motterlini et al., 2002).

Interestingly, there are recent attempts to translate the promising findings with CO inhalation and administration of CO-RMs toward the human setting (Motterlini and Otterbein, 2010). The $\mathrm{CO}-\mathrm{RMs}$ have been demonstrated to provide cytoprotective effects in different in vitro (Clark et al., 2003; Sandouka et al., 2005; Sawle et al., 2005; Srisook et al., 2006; Zobi et al., 2010) and in vivo (Vera et al., 2005; Sandouka et al., 2006; Zhou et al., 2009; Wei et al., 2010) models, which urge for translation toward the clinic.

However, the potential safety issues with these compounds must be thoroughly addressed. CO-RMs are complexes of heavy metal, like nickel, cobalt, iron, or ruthenium surrounded by carbonyl groups that are released as $\mathrm{CO}$ under the appropriate conditions (Motterlini et al., 2002, 2003). Ruthenium-based CO-RMs have recently been suggested to generate cytotoxic, CO-depleted by-products in vitro (Winburn et al., 2012). However, the development of water-soluble CO-RMs (Clark et al., 2003; Foresti et al., 2004), the use of other transition metals, e.g., manganese, in the chemical structure of CO-RMs (Motterlini et al., 2002; Crook et al., 2011), and even the use of CO-RMs devoid of transition metals (Motterlini et al., 2005) may promote the development of clinically safe CO-RMs due to less confounding effects.

Bilirubin is another generated HO-effector molecule with promising clinical applications. Besides being a powerful antioxidant (Stocker et al., 1987), several studies have shown that biliverdin/bilirubin administration has cytoprotective effects during ischemia-reperfusion injury and graft rejection after transplantation (Clark et al., 2000; Fondevila et al., 2004). Also, bilirubin exerts immunomodulatory and anti-inflammatory effects (Willis et al., 1996) by down-regulating expression of inflammatory cytokines and adhesion molecules (Nakao et al., 2004), as well as by reducing immune cell infiltration (Hayashi et al., 1999; Nakao et al., 2004). 
Individuals with Gilbert's syndrome have a polymorphism in the UGT1A1 promoter and are protected against cardiovascular complications (Schwertner and Vitek, 2008). This polymorphism results in slower glucuronidation and therefore diminished excretion of bilirubin, leading to elevated bilirubin levels. Unfortunately, bilirubin is not available for human use. We and others postulated that experimentally induced mild hyperbilirubinemia would mimic the positive effects seen in Gilbert's syndrome (McCarty, 2007; Dekker et al., 2011). In a double-blind, placebo-controlled crossover design, we demonstrated that elevating bilirubin levels using the HIV protease inhibitor atazanavir indeed ameliorates vascular function in type 2 diabetes mellitus patients (Dekker et al., 2011). In addition, the redox status in these patients was improved following induction of mild hyperbilirubinemia (Dekker et al., 2011). This demonstrates for the first time the potential beneficial power of bilirubin as a novel mechanism in humans. We expect that these clinically significant protective effects of HO-effector molecules in humans strongly encourage more translational research toward the protective properties of $\mathrm{HO}$ and its effector molecules in inflammatory and fibrotic conditions.

Finally, three examples of inflammatory disorders, which are linked to organ fibrosis and in which HO-1 and its effector molecules may be of therapeutic use, are discussed in more detail.

\section{The heme-HO system in hypertrophic scarring}

Except for fast healing wounds, such as shallow scratches, most wounds will result in visible scar formation, which is a natural part of the wound healing process. However, in some individuals depending on geographic and ethnographic distribution as well as the character of the injury - excessive deposition of ECM occurs, resulting in the formation of a raised, discolored hypertrophic scar.

The involvement of the $\mathrm{HO}$ system is evident from knockout mouse models being devoid of HO-1 or HO-2, respectively. Both models demonstrate delayed wound healing due to poor response toward inflammatory and oxidative insults (Braun et al., 2002; Seta et al., 2006; Deshane et al., 2007; Bellner et al., 2008, 2009, 2011; Patil et al., 2008; Kovtunovych et al., 2010; Halilovic et al., 2011). Also, pharmacological inhibition of $\mathrm{HO}$ activity has a negative impact on dermal wound healing (Grochot-Przeczek et al., 2009).

Also in dermal wound healing, the duality of heme is evident. Local accumulation of free heme liberated by spontaneous degradation of hemoglobin at the wound site may promote free radical formation and oxidative damage (Balla et al., 1991, 2000; Jeney et al., 2002). We have postulated that this injury-derived heme may be the trigger that initiates the inflammatory and the innate immunity response (Wagener et al., 2003a). To rapidly cope with oxidative stress, dermal fibroblasts are capable to rapidly induce HO-1 expression as a feedback response, and keratinocytes contain high levels of HO-2 (Applegate et al., 1995). When HO-1 levels are increased at the wound site resolution of inflammation will take place and the wound healing cascade can enter the next phase.

Pre-induction of $\mathrm{HO}$ by daily heme administration ( $30 \mathrm{mg} / \mathrm{kg} /$ day i.p.) in a mouse excisional wound healing model enhances wound contraction by increasing cellular proliferation and collagen synthesis (Ahanger et al., 2010). HO-1 induction also resulted in reduced transcription of pro-inflammatory cytokines, e.g., TNF $\alpha$, and an up-regulated transcription of the anti-inflammatory cytokine interleukin-10 (Ahanger et al., 2010). This demonstrates that low levels of heme may promote wound healing via induction of HO-1, whereas high levels of heme may prolong oxidative and inflammatory stress and result in a profibrotic environment. Indeed, up-regulation of HO-1 expression in keratinocytes in transgenic mice bearing the HO-1 gene under the control of keratin 14 promoter resulted in improved neovascularization and accelerated wound healing (Grochot-Przeczek et al., 2009). Also, adenoviral mediated HO-1 gene delivery significantly improved dermal wound healing (Grochot-Przeczek et al., 2009).

Together, these data suggest that increased levels of HO-1 may improve wound healing and reduce dermal scarring.

Also, (myo)fibroblast apoptosis is essential in normal and hypertrophic scarring, as fibroblasts in pathological wound healing remain in the wound area and deposit excessive amounts of ECM components, contributing to fibrogenesis. At low concentrations, curcumin has been shown to induce HO expression, whereas HO-1 expression and activity was negligible at high curcumin doses (Scharstuhl et al., 2009). Despite this, HO-1 expression has been demonstrated to protect against fibroblast apoptosis induced by high concentrations of curcumin through the actions of effector molecules biliverdin/bilirubin (Scharstuhl et al., 2009). Importantly, pre-induction of HO-1 with low doses of curcumin also protected fibroblasts against curcumin-induced apoptosis (Scharstuhl et al., 2009). This suggest that curcumin in high doses may affect pathological scar formation through affecting fibroblast apoptosis, while HO-1 and its effector molecules can fine-tune this response.

\section{The heme-HO system as therapeutic target in hepatic and pancreatic fibrosis}

The current therapeutic options in specific treatment of both hepatic (Popov and Schuppan, 2009) as well as pancreatic fibrosis (Braganza et al., 2011) are only limited and novel therapeutic options are urgently needed. Interestingly, independent groups have demonstrated that specific overexpression of HO-1 had an inhibitory effect on chronic viral hepatitis (Zhu et al., 2008; Hou et al., 2010) as one of the major causes of hepatic fibrosis. Exposure to high levels of heme has been demonstrated to result in inflammatory leukocyte influx and fibrosis into the liver (Wagener et al., 2001b; Tolosano et al., 2002). Moreover, in a more recent study pharmacological HO-1 induction via CoPPIX has been shown to prevent liver fibrosis in a Mdr2 knockout mice (Barikbin et al., 2012). Importantly, in this report up-regulation of HO-1 not only reduced activation of HSCs, but also reversed established hepatic fibrosis in this mouse model.

Heme exposure has also shown to strongly promote inflammation in the pancreas, as illustrated by increased vascular permeabilization (Wagener et al., 2001b). HO-1 might also serve as a therapeutic target in pancreatic fibrosis. Schwer et al. (2008) have shown that up-regulation of HO-1 by curcumin inhibited PSC proliferation, which plays a crucial role in the progression of pancreatic fibrosis. These findings have been extended in a more recent report, in which PSC proliferation was inhibited via activation of the p38 MAPK/HO-1 pathway (Schwer et al., 2010). Moreover, these authors also indicated that the protective effect on PSC may be mediated via $\mathrm{HO}-1$-dependent up-regulation of the cell cycle inhibitor p21/CIP-1 (Schwer et al., 2010). 


\section{The heme-HO system in CTR}

A late but severe clinical complication after solid organ transplantation is CTR, which is currently considered the major limiting factor for long-term graft survival in particular in kidney and heart transplantation (Mitchell, 2009). A hallmark of CTR is TV, also termed graft vascular disease or allograft arteriopathy, in which the success rate of current therapeutic regimens including treatment with immunosuppressive drugs is very poor (Cornell et al., 2008). Pathologic features of TV include diffuse concentric intimal hyperplasia and adventitial sclerosis due to proliferation of various cell types of the vascular wall.

Survival of cardiac xenografts has been shown to be critically dependent on the expression of endothelial HO-1 (Soares et al., 1998). Accordingly, targeted overexpression of HO-1 via a gene therapy approach has been demonstrated to protect against TV and to cause a prolonged survival of chronic allogenic rejection of aortic vascular transplants in a rat model (Chauveau et al., 2002). Additionally, HO-1 activity has been shown to reduce atherosclerosis (Bouche et al., 2002; Ferran, 2006; Du et al., 2007), which could further contribute to a higher transplantation success rate.

Although the underlying mechanisms of how HO-1 mediates its protective effects are not well understood, one major beneficial effect of HO-1 may be its anti-proliferative effects in the vasculature (Valenzuela and Reed, 2011), which has previously also been shown in an experimental angioplasty rat model (Duckers et al., 2001). In corroboration, an increasing number of studies have proven HO-1 activity to be important for transplant graft survival (Ollinger and Pratschke, 2010), as HO-1 expression induction improves recipient immune tolerance (see reviews of Soares and Bach, 2007; Blancou et al., 2011) and donor graft survival after ischemia/reperfusion injury (for recent reviews, see Ferenbach et al., 2010; Sass et al., 2012).

The beneficial effects of HO-1 activity have been linked to the induction level of $\mathrm{HO}-1$, as $\mathrm{HO}-1$ gene promoter polymorphisms affect transplantation outcome (Immenschuh and Ramadori, 2000; Baan et al., 2004; Geuken et al., 2005; Holweg et al., 2005; Courtney et al., 2007; Gerbitz et al., 2008). However, it is not only the direct effect of $\mathrm{HO}-1$ on limiting heme levels in injury sites that mediates the beneficial outcome of HO-1 activity. Also, the cytoprotective and anti-inflammatory effects of the end products generated by heme degradation, $\mathrm{CO}$ and biliverdin/bilirubin, have proven pivotal in improving the success of graft transplantation (Soares et al., 1998; Immenschuh and Ramadori, 2000; Kato et al., 2003; Nakao et al., 2004; Lee et al., 2007; Brugger et al., 2010).

The implication of heme-mediated regulation of the expression of the transcription factor and inflammatory mediator Egr-1

\section{REFERENCES}

Aarabi, S., Longaker, M. T., and Gurtner, G. C. (2007). Hypertrophic scar formation following burns and trauma: new approaches to treatment. PLoS Med. 4, e234. doi:10.1371/journal.pmed. 0040234

Abraham, N. G., and Kappas, A. (2008). Pharmacological and clinical aspects of heme oxygenase. Pharmacol. Rev. 60, 79-127.

Abraham, N. G., Lin, J. H., Schwartzman, M. L., Levere, R. D., and Shibahara, S. (1988). The physiological significance of heme oxygenase. Int. J. Biochem. 20, 543-558.

Ahanger, A. A., Prawez, S., Leo, M. D., Kathirvel, K., Kumar, D., Tandan, S. K., and Malik, J. in atherosclerosis may have a significant impact on the success rate of graft survival after transplantation, as atherosclerosis is one of the causative agents for graft rejection and transplantation failure. Interestingly, HO-1 effects have been associated with its functional interaction with the cyclin-dependent kinase inhibitor p21/CIP-1, which belongs to the Cip/Kip protein family of cell proliferation inhibitors (Duckers et al., 2001). In addition, the function of p21/CIP-1 has been demonstrated to up-regulate the cellular anti-oxidant response via direct binding to the master $\mathrm{HO}-1$ gene transcriptional regulator Nrf2 (Chen et al., 2009). These findings are in keeping with a recent report showing a major regulatory role for $\mathrm{p} 21 / \mathrm{CIP}-1$ in endothelial cell proliferation in atherosclerosis (Obikane et al., 2010), and may suggest that the interplay of p21/CIP-1 with HO-1 and/or Nrf2 is involved in the pathogenesis of TV.

Together, this exemplifies that the HO system is of major interest for the development of future therapeutic approaches that take advantage of pharmacological induction of HO-1 in endothelial cells. As a precedent, it has recently been demonstrated in a rodent atherosclerosis model that $\mathrm{HO}-1$ induction by the pharmacological compound probucol had salutary effects via inhibition of vascular smooth muscle cell proliferation (Wu et al., 2006). Also, the importance of transcriptional regulation of $\mathrm{HO}-1$ further underscores the clinical significance of the HO-1 promoter polymorphisms on therapy success, and the need for personalized medicine in the future.

\section{FUTURE PERSPECTIVES}

In this review we showed examples clearly demonstrating that excess levels of heme may promote pro-oxidant, proinflammatory, and subsequently fibrotic processes, in which the HO system may have counter-regulatory effects. These effects may occur via degradation of pro-inflammatory free heme and by the cytoprotective and anti-inflammatory effects of the HO-effector molecules CO and biliverdin/bilirubin. Promising (pre)clinical data support the utilization of $\mathrm{HO}$ and its effector molecules as novel therapeutic targets to reduce tissue inflammation, oxidative stress, and fibrosis. However, in order to translate this toward the clinical setting, safe and potent inducers of $\mathrm{HO}-1$ are needed.

\section{ACKNOWLEDGMENTS}

Supported by a grant from the Dutch Burns Foundation (\#09.110), the Radboud University Nijmegen Medical Centre, and Van Leersum Foundation (Frank Wagener) and by a grant from the BMBF (FKZ 0316045B; Stephan Immenschuh).
K. (2010). Pro-healing potential of hemin: an inducer of heme oxygenase-1. Eur. J. Pharmacol. 645, 165-170.

Applegate, L. A., Noel, A., Vile, G., Frenk, E., and Tyrrell, R. M. (1995). Two genes contribute to different extents to the heme oxygenase enzyme activity measured in cultured human skin fibroblasts and keratinocytes: implications for protection against oxidant stress. Photochem. Photobiol. 61, 285-291.

Ashcroft, G. S., Yang, X., Glick, A. B., Weinstein, M., Letterio, J. L., Mizel, D. E., Anzano, M., GreenwellWild, T., Wahl, S. M., Deng, C., and Roberts, A. B. (1999). Mice lacking Smad3 show accelerated wound healing and an impaired local inflammatory response. Nat. Cell Biol. 1, 260-266. 
Ashoor, I. F., and Najafian, N. (2012). Rejection and regulation: a tight balance. Curr. Opin. Organ Transplant 17, 1-7.

Azimzadeh, A. M., Lees, J. R., Ding, Y., and Bromberg, J. S. (2011). Immunobiology of transplantation: impact on targets for large and small molecules. Clin. Pharmacol. Ther. 90, 229-242.

Baan, C., Peeters, A., Lemos, F., Uitterlinden, A., Doxiadis, I., Claas, F., Ijzermans, J., Roodnat, J., and Weimar, W. (2004). Fundamental role for HO-1 in the self-protection of renal allografts. Am. J. Transplant. 4, 811-818.

Balla, G., Jacob, H. S., Eaton, J. W., Belcher, J. D., and Vercellotti, G. M. (1991). Hemin: a possible physiological mediator of low density lipoprotein oxidation and endothelial injury. Arterioscler. Thromb. 11, 1700-1711.

Balla, J., Balla, G., Jeney, V., Kakuk, G., Jacob, H. S., and Vercellotti, G. M. (2000). Ferriporphyrins and endothelium: a 2-edged swordpromotion of oxidation and induction of cytoprotectants. Blood 95, 3442-3450.

Balla, J., Jacob, H. S., Balla, G., Nath, K., Eaton, J. W., and Vercellotti, G. M. (1993). Endothelial-cell heme uptake from heme proteins: induction of sensitization and desensitization to oxidant damage. Proc. Natl. Acad. Sci. U.S.A. 90, 9285-9289.

Balogun, E., Hoque, M., Gong, P., Killeen, E., Green, C. J., Foresti, R., Alam, J., and Motterlini, R. (2003). Curcumin activates the haem oxygenase-1 gene via regulation of Nrf2 and the antioxidantresponsive element. Biochem. J. 371, 887-895.

Barikbin, R., Neureiter, D., Wirth, J., Erhardt, A., Schwinge, D., Kluwe, J., Schramm, C., Tiegs, G., and Sass, G. (2012). Induction of heme oxygenase 1 prevents progression of liver fibrosis in Mdr2 knockout mice. Hepatology 55, 553-562.

Barzegar, A., and Moosavi-Movahedi, A. A. (2011). Intracellular ROS protection efficiency and free radical-scavenging activity of curcumin. PLoS ONE 6, e26012. doi:10.1371/journal.pone.0026012

Bauer, M., Huse, K., Settmacher, U., and Claus, R. A. (2008). The heme oxygenase-carbon monoxide system: regulation and role in stress response and organ failure. Intensive Care Med. 34, 640-648.

Belcher, J. D., Mahaseth, H., Welch, T. E., Otterbein, L. E., Hebbel, R. P., and Vercellotti, G. M. (2006).
Heme oxygenase- 1 is a modulator of inflammation and vaso-occlusion in transgenic sickle mice. J. Clin. Invest. 116, 808-816.

Bellner, L., Martinelli, L., Halilovic, A., Patil, K., Puri, N., Dunn, M. W., Regan, R. F., and Schwartzman, M. L. (2009). Heme oxygenase-2 deletion causes endothelial cell activation marked by oxidative stress, inflammation, and angiogenesis. $J$. Pharmacol. Exp. Ther. 331, 925-932.

Bellner, L., Vitto, M., Patil, K. A., Dunn, M. W., Regan, R., and LaniadoSchwartzman, M. (2008). Exacerbated corneal inflammation and neovascularization in the HO-2 null mice is ameliorated by biliverdin. Exp. Eye Res. 87, 268-278.

Bellner, L., Wolstein, J., Patil, K. A., Dunn, M. W., and LaniadoSchwartzman, M. (2011). Biliverdin rescues the HO-2 null mouse phenotype of unresolved chronic inflammation following corneal epithelial injury. Invest. Ophthalmol. Vis. Sci. 52, 3246-3253.

Blancou, P., Tardif, V., Simon, T., Remy, S., Carreno, L., Kalergis, A., and Anegon, I. (2011). Immunoregulatory properties of heme oxygenase1. Methods Mol. Biol. 677, 247-268.

Blaschke, F., Bruemmer, D., and Law, R. E. (2004). Egr-1 is a major vascular pathogenic transcription factor in atherosclerosis and restenosis. Rev. Endocr. Metab. Disord. 5, 249-254.

Bock, O., Schmid-Ott, G., Malewski, P., and Mrowietz, U. (2006). Quality of life of patients with keloid and hypertrophic scarring. Arch. Dermatol. Res. 297, 433-438.

Bouche, D., Chauveau, C., Roussel, J. C., Mathieu, P., Braudeau, C., Tesson, L., Soulillou, J. P., Iyer, S., Buelow, R., and Anegon, I. (2002). Inhibition of graft arteriosclerosis development in rat aortas following heme oxygenase-1 gene transfer. Transpl. Immunol. 9, 235-238.

Braganza, J. M., Lee, S. H., Mccloy, R. F., and Mcmahon, M. J. (2011). Chronic pancreatitis. Lancet 377, 1184-1197.

Braun, S., Hanselmann, C., Gassmann, M. G., Auf Dem Keller, U., BornBerclaz, C., Chan, K., Kan, Y. W., and Werner, S. (2002). Nrf2 transcription factor, a novel target of keratinocyte growth factor action which regulates gene expression and inflammation in the healing skin wound. Mol. Cell. Biol. 22, 5492-5505.

Brissett, A. E., and Sherris, D. A. (2001). Scar contractures, hypertrophic scars, and keloids. Facial Plast. Surg. 17, 263-272.
Brouard, S., Otterbein, L. E., Anrather, J., Tobiasch, E., Bach, F. H., Choi, A. M., and Soares, M. P. (2000). Carbon monoxide generated by heme oxygenase 1 suppresses endothelial cell apoptosis. J. Exp. Med. 192, 1015-1026.

Brugger, J., Schick, M. A., Brock, R. W., Baumann, A., Muellenbach, R. M., Roewer, N., and Wunder, C. (2010). Carbon monoxide has antioxidative properties in the liver involving p38 MAP kinase pathway in a murine model of systemic inflammation. Microcirculation 17, 504-513.

Cambos, M., Bazinet, S., Abed, E., Sanchez-Dardon, J., Bernard, C., Moreau, R., Olivier, M., and Scorza, T. (2010). The IL-12p70/IL-10 interplay is differentially regulated by free heme and hemozoin in murine bone-marrow-derived macrophages. Int. J. Parasitol. 40, 1003-1012.

Cambos, M., and Scorza, T. (2011). Robust erythrophagocytosis leads to macrophage apoptosis via a heminmediated redox imbalance: role in hemolytic disorders. J. Leukoc. Biol. 89, 159-171.

Cerny, D., Lekic, N., Vanova, K., Muchova, L., Horinek, A., Kmonickova, E., Zidek, Z., Kamenikova, L., and Farghali, H. (2011). Hepatoprotective effect of curcumin in lipopolysaccharide/-galactosamine model of liver injury in rats: relationship to $\mathrm{HO}-1 / \mathrm{CO}$ antioxidant system. Fitoterapia 82, 786-791.

Chauveau, C., Bouchet, D., Roussel, J. C., Mathieu, P., Braudeau, C., Renaudin, K., Tesson, L., Soulillou, J. P., Iyer, S., Buelow, R., and Anegon, I. (2002). Gene transfer of heme oxygenase-1 and carbon monoxide delivery inhibit chronic rejection. Am. J. Transplant. 2, 581-592.

Chen, W., Sun, Z., Wang, X. J., Jiang, T., Huang, Z., Fang, D., and Zhang, D. D. (2009). Direct interaction between Nrf2 and p21(Cip1/WAF1) upregulates the Nrf2-mediated antioxidant response. Mol. Cell 34, 663-673.

Chettibi, S., Ferguson, W. J., Gallin, J. L., and Snyderman, R. (1999). "Wound repair: an overview," in Inflammation: Basic Principles and Clinical Correlates eds J. Gallin and R. Snyderman (Philadelphia: Lippincott Williams \& Wilkins), 865-881.

Chlopicki, S., Olszanecki, R., Marcinkiewicz, E., Lomnicka, M., and Motterlini, R. (2006). Carbon monoxide released by CORM-3 inhibits human platelets by a mechanism independent of soluble guanylate cyclase. Cardiovasc. Res. 71, 393-401.

Chora, A. A., Fontoura, P., Cunha, A., Pais, T. F., Cardoso, S., Ho, P. P., Lee, L. Y., Sobel, R. A., Steinman, L., and Soares, M. P. (2007). Heme oxygenase-1 and carbon monoxide suppress autoimmune neuroinflammation. J. Clin. Invest. 117, 438-447.

Clark, J. E., Foresti, R., Sarathchandra, P., Kaur, H., Green, C. J., and Motterlini, R. (2000). Heme oxygenase-1derived bilirubin ameliorates postischemic myocardial dysfunction. Am. J. Physiol. Heart Circ. Physiol. 278, H643-H651

Clark, J. E., Naughton, P., Shurey, S., Green, C. J., Johnson, T. R., Mann, B. E., Foresti, R., and Motterlini, R. (2003). Cardioprotective actions by a water-soluble carbon monoxidereleasing molecule. Circ. Res. 93, e2-e8.

Cornell, L. D., Smith, R. N., and Colvin, R. B. (2008). Kidney transplantation: mechanisms of rejection and acceptance. Annu. Rev. Pathol. 3, 189-220.

Cosgrove, S., Chotirmall, S. H., Greene, C. M., and Mcelvaney, N. G. (2011). Pulmonary proteases in the cystic fibrosis lung induce interleukin 8 expression from bronchial epithelial cells via a heme/meprin/epidermal growth factor receptor/Toll-like receptor pathway. J. Biol. Chem. 286, 7692-7704.

Courtney, A. E., Mcnamee, P. T., Middleton, D., Heggarty, S., Patterson, C. C. and Maxwell, A. P. (2007). Association of functional heme oxygenase-1 gene promoter polymorphism with renal transplantation outcomes. Am. J. Transplant. 7, 908-913.

Crook, S. H., Mann, B. E., Meijer, A. J., Adams, H., Sawle, P., Scapens, D., and Motterlini, R. (2011). [Mn $(\mathrm{CO}) 4\{\mathrm{~S} 2 \mathrm{CNMe}(\mathrm{CH} 2 \mathrm{CO} 2 \mathrm{H})\}]$, a new water-soluble CO-releasing molecule. Dalton Trans. 40, 4230-4235.

Deitch, E. A., Wheelahan, T. M., Rose, M. P., Clothier, J., and Cotter, J. (1983). Hypertrophic burn scars: analysis of variables. J. Trauma 23, 895-898.

Dekker, D., Dorresteijn, M. J., Pijnenburg, M., Heemskerk, S., Rasing-Hoogveld, A., Burger, D. M., Wagener, F. A., and Smits, P. (2011). The bilirubin-increasing drug atazanavir improves endothelial function in patients with type 2 diabetes mellitus. Arterioscler. Thromb. Vasc. Biol. 31, 458-463.

Deshane, J., Chen, S., Caballero, S., Grochot-Przeczek, A., Was, H., Li, C. S., Lach, R., Hock, T. D., Chen, 
B., Hill-Kapturczak, N., Siegal, G. P., Dulak, J., Jozkowicz, A., Grant, M. B., and Agarwal, A. (2007). Stromal cellderived factor 1 promotes angiogenesis via a heme oxygenase 1dependent mechanism. J. Exp. Med. 204, 605-618.

Dhakshinamoorthy, S., Jain, A. K., Bloom, D. A., and Jaiswal, A. K. (2005). Bach1 competes with Nrf2 leading to negative regulation of the antioxidant response element (ARE)-mediated $\mathrm{NAD}(\mathrm{P}) \mathrm{H}$ :quinone oxidoreductase 1 gene expression and induction in response to antioxidants. J. Biol. Chem. 280, 16891-16900.

Doberer, D., Haschemi, A., Andreas, M., Zapf, T. C., Clive, B., Jeitler, M., Heinzl, H., Wagner, O., Wolzt, M., and Bilban, M. (2010). Haem arginate infusion stimulates haem oxygenase-1 expression in healthy subjects. Br. J. Pharmacol. 161, 1751-1762.

Du, D., Chang, S., Chen, B., Zhou, H., and Chen, Z. K. (2007). Adenovirusmediated heme oxygenase transfer inhibits graft arteriosclerosis in rat aortic transplants. Transplant. Proc. 39, 3446-3448.

Duckers, H. J., Boehm, M., True, A. L., Yet, S. F., San, H., Park, J. L., Clinton Webb, R., Lee, M. E., Nabel, G. J., and Nabel, E. G. (2001). Heme oxygenase-1 protects against vascular constriction and proliferation. Nat. Med. 7, 693-698.

Duffield, J. S., Forbes, S. J., Constandinou, C. M., Clay, S., Partolina, M., Vuthoori, S., Wu, S., Lang, R., and Iredale, J. P. (2005). Selective depletion of macrophages reveals distinct, opposing roles during liver injury and repair. J. Clin. Invest. 115, 56-65.

Exner, M., Minar, E., Wagner, O., and Schillinger, M. (2004). The role of heme oxygenase-1 promoter polymorphisms in human disease. Free Radic. Biol. Med. 37, 1097-1104.

Fathke, C., Wilson, L., Hutter, J., Kapoor, V., Smith, A., Hocking, A., and Isik, F. (2004). Contribution of bone marrow-derived cells to skin: collagen deposition and wound repair. Stem Cells 22, 812-822.

Ferenbach, D. A., Kluth, D. C., and Hughes, J. (2010). Hemeoxygenase1 and renal ischaemia-reperfusion injury. Nephron Exp. Nephrol. 115, e33-e37.

Ferran, C. (2006). Protective genes in the vessel wall: modulators of graft survival and function. Transplantation 82, S36-S40.

Fialkow, L., Wang, Y., and Downey, G. P. (2007). Reactive oxygen and nitrogen species as signaling molecules regulating neutrophil function. Free Radic. Biol. Med. 42, 153-164.

Figueiredo, R. T., Fernandez, P. L., Mourao-Sa, D. S., Porto, B. N., Dutra, F. F., Alves, L. S., Oliveira, M. F., Oliveira, P. L., Graca-Souza, A. V., and Bozza, M. T. (2007). Characterization of heme as activator of Toll-like receptor 4. J. Biol. Chem. 282, 20221-20229.

Fondevila, C., Shen, X. D., Tsuchiyashi, S., Yamashita, K., Csizmadia, E., Lassman, C., Busuttil, R. W., KupiecWeglinski, J. W., and Bach, F. H. (2004). Biliverdin therapy protects rat livers from ischemia and reperfusion injury. Hepatology 40, 1333-1341.

Foresti, R., Hammad, J., Clark, J. E., Johnson, T. R., Mann, B. E., Friebe, A., Green, C. J., and Motterlini, R. (2004). Vasoactive properties of CORM-3, a novel water-soluble carbon monoxide-releasing molecule. Br. J. Pharmacol. 142, 453-460.

Frantz, F. W., Bettinger, D. A., Haynes, J. H., Johnson, D. E., Harvey, K. M., Dalton, H. P., Yager, D. R., Diegelmann, R. F., and Cohen, I. K. (1993). Biology of fetal repair: the presence of bacteria in fetal wounds induces an adult-like healing response. $J$. Pediatr. Surg. 28, 428-433.

Gawronska-Kozak, B., Bogacki, M., Rim, J. S., Monroe, W. T., and Manuel, J. A. (2006). Scarless skin repair in immunodeficient mice. Wound Repair Regen. 14, 265-276.

Gerbitz, A., Hillemanns, P., Schmid, C., Wilke, A., Jayaraman, R., Kolb, H. J., Eissner, G., and Holler, E. (2008). Influence of polymorphism within the heme oxygenase-I promoter on overall survival and transplantationrelated mortality after allogeneic stem cell transplantation. Biol. Blood Marrow Transplant. 14, 1180-1189.

Geuken, E., Buis, C. I., Visser, D. S., Blokzijl, H., Moshage, H., Nemes, B., Leuvenink, H. G., De Jong, K. P., Peeters, P. M., Slooff, M. J., and Porte, R. J. (2005). Expression of heme oxygenase-1 in human livers before transplantation correlates with graft injury and function after transplantation. Am. J. Transplant. 5, 1875-1885.

Goren, I., Allmann, N., Yogev, N., Schurmann, C., Linke, A., Holdener, M., Waisman, A., Pfeilschifter, J., and Frank, S. (2009). A transgenic mouse model of inducible macrophage depletion: effects of diphtheria toxin-driven lysozyme M-specific cell lineage ablation on wound inflammatory, angiogenic, and contractive processes. Am. J. Pathol. 175, 132-147.
Gozzelino, R., Jeney, V., and Soares, M. P. (2010). Mechanisms of cell protection by heme oxygenase- 1 . Annu. Rev. Pharmacol. Toxicol. 50, 323-354.

Grochot-Przeczek, A., Dulak, J., and Jozkowicz, A. (2012). Haem oxygenase-1: non-canonical roles in physiology and pathology. Clin. Sci. 122, 93-103.

Grochot-Przeczek, A., Lach, R. Mis, J., Skrzypek, K., Gozdecka, M., Sroczynska, P., Dubiel, M. Rutkowski, A., Kozakowska, M. Zagorska, A., Walczynski, J., Was, H., Kotlinowski, J., Drukala, J., Kurowski, K., Kieda, C., Herault, Y., Dulak, J., and Jozkowicz, A. (2009). Heme oxygenase-1 accelerates cutaneous wound healing in mice. PLoS ONE 4, e5803. doi:10.1371/journal.pone.0005803

Grosser, N., Hemmerle, A., Berndt, G., Erdmann, K., Hinkelmann, U., Schurger, S., Wijayanti, N., Immenschuh, S., and Schroder, H. (2004). The antioxidant defense protein heme oxygenase 1 is a novel target for statins in endothelial cells. Free Radic. Biol. Med. 37, 2064-2071.

Guo, S., and Dipietro, L. A. (2010). Factors affecting wound healing. J. Dent. Res. 89, 219-229.

Halilovic, A., Patil, K. A., Bellner, L., Marrazzo, G., Castellano, K., Cullaro, G., Dunn, M. W., and Schwartzman, M. L. (2011). Knockdown of heme oxygenase-2 impairs corneal epithelial cell wound healing. J. Cell. Physiol. 226, 1732-1740.

Halliwell, B., and Gutteridge, J. M. (1984). Oxygen toxicity, oxygen radicals, transition metals and disease. Biochem. J. 219, 1-14.

Hao, K., Hanawa, H., Ding, L., Ota, Y., Yoshida, K., Toba, K., Ogura, M., Ito, H., Kodama, M., and Aizawa, Y. (2011). Free heme is a danger signal inducing expression of proinflammatory proteins in cultured cells derived from normal rat hearts. $\mathrm{Mol}$. Immunol. 48, 1191-1202.

Harty, M., Neff, A. W., King, M. W., and Mescher, A. L. (2003). Regeneration or scarring: an immunologic perspective. Dev. Dyn. 226, 268-279.

Hasan, R. N., and Schafer, A. I. (2008). Hemin upregulates Egr-1 expression in vascular smooth muscle cells via reactive oxygen species ERK-1/2Elk-1 and NF-kappaB. Circ. Res. 102, 42-50.

Hayashi, S., Takamiya, R., Yamaguchi, T., Matsumoto, K., Tojo, S. J., Tamatani, T., Kitajima, M., Makino, N., Ishimura, Y., and Suematsu, M. (1999). Induction of heme oxygenase-1 suppresses venular leukocyte adhesion elicited by oxidative stress: role of bilirubin generated by the enzyme. Circ. Res. 85, 663-671.

Hernandez-Gea, V., and Friedman, S. L. (2011). Pathogenesis of liver fibrosis. Annu. Rev. Pathol. 6, 425-456.

Holweg, C. T., Balk, A. H., Uitterlinden, A. G., Niesters, H. G., Maat, L. P., Weimar, W., and Baan, C. C. (2005). Functional heme oxygenase-1 promoter polymorphism in relation to heart failure and cardiac transplantation. J. Heart Lung Transplant. 24, 493-497.

Hou, W., Tian, Q., Zheng, J., and Bonkovsky, H. L. (2010). MicroRNA-196 represses Bach1 protein and hepatitis $\mathrm{C}$ virus gene expression in human hepatoma cells expressing hepatitis $\mathrm{C}$ viral proteins. Hepatology 51, 1494-1504.

Hunt, T. K., Hopf, H., and Hussain, Z. (2000). Physiology of wound healing. Adv. Skin Wound Care 13, 6-11.

Igarashi, K., and Sun, J. (2006). The heme-Bach1 pathway in the regulation of oxidative stress response and erythroid differentiation. Antioxid. Redox Signal. 8, 107-118.

Immenschuh, S., and Ramadori, G. (2000). Gene regulation of heme oxygenase- 1 as a therapeutic target. Biochem. Pharmacol. 60, 1121-1128.

Iwasaki, K., Mackenzie, E. L., Hailemariam, K., Sakamoto, K., and Tsuji, Y. (2006). Hemin-mediated regulation of an antioxidant-responsive element of the human ferritin $\mathrm{H}$ gene and role of Ref- 1 during erythroid differentiation of K562 cells. Mol. Cell. Biol. 26, 2845-2856.

Jeney, V., Balla, J., Yachie, A., Varga, Z., Vercellotti, G. M., Eaton, J. W., and Balla, G. (2002). Pro-oxidant and cytotoxic effects of circulating heme. Blood 100, 879-887.

Kanakiriya, S. K., Croatt, A. J., Haggard, J. J., Ingelfinger, J. R., Tang, S. S., Alam, J., and Nath, K. A. (2003). Heme: a novel inducer of MCP-1 through HO-dependent and HO-independent mechanisms. Am. J. Physiol. Renal Physiol. 284, F546F554.

Kartikasari, A. E., Wagener, F. A., Yachie, A., Wiegerinck, E. T., Kemna, E. H., and Winkels, D. W. (2009). Hepcidin suppression and defective iron recycling account for dysregulation of iron homeostasis in heme oxygenase-1 deficiency. J. Cell. Mol. Med. 13, 3091-3102.

Kato, Y., Shimazu, M., Kondo, M., Uchida, K., Kumamoto, Y., Wakabayashi, G., Kitajima, M., and Suematsu, M. (2003). Bilirubin rinse: 
a simple protectant against the rat liver graft injury mimicking heme oxygenase-1 preconditioning. Нераtology 38, 364-373.

Kawashima, A., Oda, Y., Yachie, A., Koizumi, S., and Nakanishi, I. (2002). Heme oxygenase-1 deficiency: the first autopsy case. Hum. Pathol. 33, 125-130.

Keyse, S. M., and Tyrrell, R. M. (1989). Heme oxygenase is the major 32$\mathrm{kDa}$ stress protein induced in human skin fibroblasts by UVA radiation, hydrogen peroxide, and sodium arsenite. Proc. Natl. Acad. Sci. U.S.A. 86, 99-103.

Kovtunovych, G., Eckhaus, M. A., Ghosh, M. C., Ollivierre-Wilson, H., and Rouault, T. A. (2010). Dysfunction of the heme recycling system in heme oxygenase 1-deficient mice: effects on macrophage viability and tissue iron distribution. Blood 116, 6054-6062.

Larsen, R., Gozzelino, R., Jeney, V., Tokaji, L., Bozza, F. A., Japiassu, A. M., Bonaparte, D., Cavalcante, M. M., Chora, A., Ferreira, A., Marguti, I., Cardoso, S., Sepulveda, N., Smith, A., and Soares, M. P. (2010). A central role for free heme in the pathogenesis of severe sepsis. Sci. Transl. Med. 2, 51 ra71.

Lee, J. C., Kinniry, P. A., Arguiri, E., Serota, M., Kanterakis, S., Chatterjee, S., Solomides, C. C., Javvadi, P., Koumenis, C., Cengel, K. A., and Christofidou-Solomidou, M. (2010). Dietary curcumin increases antioxidant defenses in lung, ameliorates radiation-induced pulmonary fibrosis, and improves survival in mice. Radiat. Res. 173, 590-601.

Lee, S. S., Gao, W., Mazzola, S., Thomas, M. N., Csizmadia, E., Otterbein, L. E., Bach, F. H., and Wang, H. (2007). Heme oxygenase-1, carbon monoxide, and bilirubin induce tolerance in recipients toward islet allografts by modulating $\mathrm{T}$ regulatory cells. FASEB J. 21, 3450-3457.

Lee, T. S., Chang, C. C., Zhu, Y., and Shyy, J. Y. (2004). Simvastatin induces heme oxygenase-1: a novel mechanism of vessel protection. Circulation 110, 1296-1302.

Li, C., Hossieny, P., Wu, B. J., Qawasmeh, A., Beck, K., and Stocker, R. (2007). Pharmacologic induction of heme oxygenase-1. Antioxid. Redox Signal. 9, 2227-2239.

Loke, W. M., Proudfoot, J. M., Hodgson, J. M., Mckinley, A. J., Hime, N., Magat, M., Stocker, R., and Croft, K. D. (2010). Specific dietary polyphenols attenuate atherosclerosis in apolipoprotein
E-knockout mice by alleviating inflammation and endothelial dysfunction. Arterioscler. Thromb. Vasc. Biol. 30, 749-757.

Loke, W. M., Proudfoot, J. M., Stewart, S., Mckinley, A. J., Needs, P. W., Kroon, P. A., Hodgson, J. M., and Croft, K. D. (2008). Metabolic transformation has a profound effect on anti-inflammatory activity of flavonoids such as quercetin: lack of association between antioxidant and lipoxygenase inhibitory activity. Biochem. Pharmacol. 75, 1045-1053.

Loots, M. A., Lamme, E. N., Zeegelaar, J., Mekkes, J. R., Bos, J. D., and Middelkoop, E. (1998). Differences in cellular infiltrate and extracellular matrix of chronic diabetic and venous ulcers versus acute wounds. J. Invest. Dermatol. 111, 850-857.

Ma, E., Mar, V., Varigos, G., Nicoll, A., and Ross, G. (2011). Haem arginate as effective maintenance therapy for hereditary coproporphyria. Australas. J. Dermatol. 52, 135-138.

Ma, J. L., Yang, P. Y., Rui, Y. C., Lu, L., Kang, H., and Zhang, J. (2007). Hemin modulates cytokine expressions in macrophage-derived foam cells via heme oxygenase-1 induction. J. Pharmacol. Sci. 103, 261-266.

MacLeod, A. K., Mcmahon, M., Plummer, S. M., Higgins, L. G., Penning, T. M., Igarashi, K., and Hayes, J. D. (2009). Characterization of the cancer chemopreventive NRF2dependent gene battery in human keratinocytes: demonstration that the KEAP1-NRF2 pathway, and not the BACH1-NRF2 pathway, controls cytoprotection against electrophiles as well as redox-cycling compounds. Carcinogenesis 30, 1571-1580.

Maines, M. D. (1988). Heme oxygenase: function, multiplicity, regulatory mechanisms, and clinical applications. FASEB J. 2, 2557-2568.

Mandal, P., Park, P. H., MacMullen, M. R., Pratt, B. T., and Nagy, L. E. (2010). The anti-inflammatory effects of adiponectin are mediated via a heme oxygenase-1-dependent pathway. Hepatology 51, 1420-1429.

Marrazzo, G., Bellner, L., Halilovic, A., Li Volti, G., Drago, F., Dunn, M. W., and Schwartzman, M. L. (2011). The role of neutrophils in corneal wound healing in HO-2 null mice. PLoS ONE 6, e21180. doi:10.1371/journal.pone.0021180

Martin, P., and Leibovich, S. J. (2005). Inflammatory cells during wound repair: the good, the bad and the ugly. Trends Cell Biol. 15, 599-607.

Mathew, L. K., Sengupta, S., Kawakami, A., Andreasen, E. A., Lohr, C. V.,
Loynes, C. A., Renshaw, S. A., Peterson, R. T., and Tanguay, R. L. (2007). Unraveling tissue regeneration pathways using chemical genetics. J. Biol. Chem. 282, 35202-35210.

Mayr, F. B., Spiel, A., Leitner, J., Marsik, C., Germann, P., Ullrich, R., Wagner, O., and Jilma, B. (2005). Effects of carbon monoxide inhalation during experimental endotoxemia in humans. Am. J. Respir. Crit. Care Med. 171, 354-360.

McCaffrey, T. A., Fu, C., Du, B., Eksinar, S., Kent, K. C., Bush, H. Jr. Kreiger, K., Rosengart, T., Cybulsky, M. I., Silverman, E. S., and Collins, T. (2000). High-level expression of Egr-1 and Egr-1-inducible genes in mouse and human atherosclerosis. $J$. Clin. Invest. 105, 653-662.

McCarty, M. F. (2007). "Iatrogenic Gilbert syndrome" - a strategy for reducing vascular and cancer risk by increasing plasma unconjugated bilirubin. Med. Hypotheses 69 , 974-994.

McNally, S. J., Harrison, E. M., Ross, J. A., Garden, O. J., and Wigmore, S. J. (2007). Curcumin induces heme oxygenase 1 through generation of reactive oxygen species, p38 activation and phosphatase inhibition. Int. J. Mol. Med. 19, 165-172.

Mitchell, R. N. (2009). Graft vascular disease: immune response meets the vessel wall. Annu. Rev. Pathol. 4, 19-47.

Moore, B. A., Overhaus, M., Whitcomb, J., Ifedigbo, E., Choi, A. M., Otterbein, L. E., and Bauer, A. J. (2005). Brief inhalation of low-dose carbon monoxide protects rodents and swine from postoperative ileus. Crit. Care Med. 33, 1317-1326.

Mori, R., Power, K. T., Wang, C. M., Martin, P., and Becker, D. L. (2006). Acute downregulation of connexin43 at wound sites leads to a reduced inflammatory response, enhanced keratinocyte proliferation and wound fibroblast migration. $J$. Cell. Sci. 119, 5193-5203.

Mori, R., Shaw, T. J., and Martin, P. (2008). Molecular mechanisms linking wound inflammation and fibrosis: knockdown of osteopontin leads to rapid repair and reduced scarring. J. Exp. Med. 205, 43-51.

Motterlini, R., Clark, J. E., Foresti, R., Sarathchandra, P., Mann, B. E., and Green, C. J. (2002). Carbon monoxide-releasing molecules: characterization of biochemical and vascular activities. Circ. Res. 90, E17E24.

Motterlini, R., Foresti, R., Bassi, R., and Green, C. J. (2000). Curcumin, an antioxidant and anti-inflammatory agent, induces heme oxygenase-1 and protects endothelial cells against oxidative stress. Free Radic. Biol. Med. 28, 1303-1312.

Motterlini, R., Mann, B. E., Johnson, T. R., Clark, J. E., Foresti, R., and Green, C. J. (2003). Bioactivity and pharmacological actions of carbon monoxide-releasing molecules. Curr. Pharm. Des. 9, 2525-2539.

Motterlini, R., and Otterbein, L. E. (2010). The therapeutic potential of carbon monoxide. Nat. Rev. Drug Discov. 9, 728-743.

Motterlini, R., Sawle, P., Hammad, J., Bains, S., Alberto, R., Foresti, R., and Green, C. J. (2005). CORM-Al: a new pharmacologically active carbon monoxide-releasing molecule. FASEB J. 19, 284-286.

Naidu, S., Vijayan, V., Santoso, S., Kietzmann, T., and Immenschuh, S. (2009). Inhibition and genetic deficiency of p38 MAPK up-regulates heme oxygenase-1 gene expression via Nrf2. J. Immunol. 182, 7048-7057.

Nakajima, O., Takahashi, S., Harigae, H., Furuyama, K., Hayashi, N. Sassa, S., and Yamamoto, M. (1999). Heme deficiency in erythroid lineage causes differentiation arrest and cytoplasmic iron overload. EMBO J 18, 6282-6289.

Nakamichi, I., Habtezion, A., Zhong, B., Contag, C. H., Butcher, E. C., and Omary, M. B. (2005). Heminactivated macrophages home to the pancreas and protect from acute pancreatitis via heme oxygenase1 induction. J. Clin. Invest. 115, 3007-3014.

Nakao, A., Otterbein, L. E., Overhaus, M., Sarady, J. K., Tsung, A., Kimizuka, K., Nalesnik, M. A., Kaizu, T., Uchiyama, T., Liu, F., Murase, N., Bauer, A. J., and Bach, F. H. (2004). Biliverdin protects the functional integrity of a transplanted syngeneic small bowel. Gastroenterology 127, 595-606.

Nakao, A., Schmidt, J., Harada, T., Tsung, A., Stoffels, B., Cruz, R. J. Jr., Kohmoto, J., Peng, X., Tomiyama, K., Murase, N., Bauer, A. J., and Fink, M. P. (2006). A single intraperitoneal dose of carbon monoxidesaturated ringer's lactate solution ameliorates postoperative ileus in mice. J. Pharmacol. Exp. Ther. 319, 1265-1275.

Natarajan, R., Fisher, B. J., and Fowler, A. A. III. (2007). Hypoxia inducible factor-1 modulates hemin-induced IL-8 secretion in microvascular endothelium. Microvasc. Res. 73, 163-172. 
Nath, K. A., Balla, J., Croatt, A. J., and Vercellotti, G. M. (1995). Heme protein-mediated renal injury: a protective role for 21-aminosteroids in vitro and in vivo. Kidney Int. 47, 592-602.

Neto, J. S., Nakao, A., Toyokawa, H., Nalesnik, M. A., Romanosky, A. J., Kimizuka, K., Kaizu, T., Hashimoto, N., Azhipa, O., Stolz, D. B., Choi, A. M., and Murase, N. (2006). Lowdose carbon monoxide inhalation prevents development of chronic allograft nephropathy. Am. J. Physiol. Renal Physiol. 290, F324-F334.

Oakley, F., Mann, J., Nailard, S., Smart, D. E., Mungalsingh, N., Constandinou, C., Ali, S., Wilson, S. J., Millward-Sadler, H., Iredale, J. P., and Mann, D. A. (2005). Nuclear factor-kappaB1 (p50) limits the inflammatory and fibrogenic responses to chronic injury. Am. J. Pathol. 166, 695-708.

Obikane, H., Abiko, Y., Ueno, H., Kusumi, Y., Esumi, M., and Mitsumata, M. (2010). Effect of endothelial cell proliferation on atherogenesis: a role of $\mathrm{p} 21$ (Sdi/Cip/Wafl) in monocyte adhesion to endothelial cells. Atherosclerosis 212, 116-122.

Ogawa, K., Sun, J., Taketani, S., Nakajima, O., Nishitani, C., Sassa, S., Hayashi, N., Yamamoto, M., Shibahara, S., Fujita, H., and Igarashi, K. (2001). Heme mediates derepression of Maf recognition element through direct binding to transcription repressor Bach1. EMBO J. 20, 2835-2843.

Okada, S., Muto, A., Ogawa, E., Nakanome, A., Katoh, Y., Ikawa, S., Aiba, S., Igarashi, K., and Okuyama, R. (2010). Bach1-dependent and -independent regulation of heme oxygenase- 1 in keratinocytes. J. Biol. Chem. 285, 23581-23589.

Ollinger, R., and Pratschke, J. (2010). Role of heme oxygenase-1 in transplantation. Transpl. Int. 23, 1071-1081.

Omary, M. B., Lugea, A., Lowe, A. W., and Pandol, S. J. (2007). The pancreatic stellate cell: a star on the rise in pancreatic diseases. J. Clin. Invest. 117, 50-59.

Pae, H. O., Lee, Y. C., and Chung, H. T. (2008). Heme oxygenase- 1 and carbon monoxide: emerging therapeutic targets in inflammation and allergy. Recent Pat. Inflamm. Allergy Drug Discov. 2, 159-165.

Paine, A., Eiz-Vesper, B., Blasczyk, R., and Immenschuh, S. (2010). Signaling to heme oxygenase- 1 and its antiinflammatory therapeutic potential. Biochem. Pharmacol. 80, 1895-1903.
Pamplona, A., Ferreira, A., Balla, J., Jeney, V., Balla, G., Epiphanio, S., Chora, A., Rodrigues, C. D., Gregoire, I. P., Cunha-Rodrigues, M., Portugal, S., Soares, M. P., and Mota, M. M. (2007). Heme oxygenase1 and carbon monoxide suppress the pathogenesis of experimental cerebral malaria. Nat. Med. 13, 703-710.

Park, D. J., Agarwal, A., and George, J. F. (2010). Heme oxygenase- 1 expression in murine dendritic cell subpopulations: effect on CD8+ dendritic cell differentiation in vivo. Am. J. Pathol. 176, 2831-2839.

Patil, K., Bellner, L., Cullaro, G., Gotlinger, K. H., Dunn, M. W., and Schwartzman, M. L. (2008). Heme oxygenase-1 induction attenuates corneal inflammation and accelerates wound healing after epithelial injury. Invest. Ophthalmol. Vis. Sci. 49, 3379-3386.

Paul, G., Bataille, F., Obermeier, F., Bock, J., Klebl, F., Strauch, U., Lochbaum, D., Rummele, P., Farkas, S., Scholmerich, J., Fleck, M., Rogler, G., and Herfarth, H. (2005). Analysis of intestinal haem-oxygenase-1 (HO-1) in clinical and experimental colitis. Clin. Exp. Immunol. 140, 547-555.

Popov, Y., and Schuppan, D. (2009). Targeting liver fibrosis: strategies for development and validation of antifibrotic therapies. Hepatology 50, 1294-1306.

Porto, B. N., Alves, L. S., Fernandez, P. L., Dutra, T. P., Figueiredo, R. T., Graca-Souza, A. V., and Bozza, M. T. (2007). Heme induces neutrophil migration and reactive oxygen species generation through signaling pathways characteristic of chemotactic receptors. J. Biol. Chem. 282, 24430-24436.

Poss, K. D., and Tonegawa, S. (1997). Reduced stress defense in heme oxygenase 1-deficient cells. Proc. Natl. Acad. Sci. U.S.A. 94, 10925-10930.

Racusen, L. C., and Regele, H. (2010). The pathology of chronic allograft dysfunction. Kidney Int. Suppl. 119, S27-S32.

Radhakrishnan, N., Yadav, S. P., Sachdeva, A., Pruthi, P. K., Sawhney, S., Piplani, T., Wada, T., and Yachie, A. (2011). Human heme oxygenase-1 deficiency presenting with hemolysis, nephritis, and asplenia. J. Pediatr. Hematol. Oncol. 33, 74-78.

Remy, S., Blancou, P., Tesson, L., Tardif, V., Brion, R., Royer, P. J., Motterlini, R., Foresti, R., Painchaut, M., Pogu, S., Gregoire, M., Bach,
J. M., Anegon, I., and Chauveau, C. (2009). Carbon monoxide inhibits TLR-induced dendritic cell immunogenicity. J. Immunol. 182, 1877-1884.

Rucker, M., Schafer, T., Roesken, F., Spitzer, W. J., Bauer, M., and Menger, M. D. (2001). Reduction of inflammatory response in composite flap transfer by local stress conditioninginduced heat-shock protein 32 . Surgery 129, 292-301.

Rushworth, S. A., and O'Connell, M. A. (2004). Haem oxygenase-1 in inflammation. Biochem. Soc. Trans. 32, 1093-1094.

Ryan, K. A., Smith, M. F. Jr., Sanders, M. K., and Ernst, P. B. (2004). Reactive oxygen and nitrogen species differentially regulate Toll-like receptor 4mediated activation of NF-kappa B and interleukin-8 expression. Infect. Immun. 72, 2123-2130.

Ryter, S. W., Alam, J., and Choi, A. M. (2006). Heme oxygenase$1 /$ carbon monoxide: from basic science to therapeutic applications. Physiol. Rev. 86, 583-650.

Ryter, S. W., and Choi, A. M. (2009). Heme oxygenase-1/carbon monoxide: from metabolism to molecular therapy. Am. J. Respir. Cell Mol. Biol. 41, 251-260.

Ryter, S. W., and Tyrrell, R. M. (2000). The heme synthesis and degradation pathways: role in oxidant sensitivity. Heme oxygenase has both pro- and antioxidant properties. Free Radic. Biol. Med. 28, 289-309.

Saito, Y., Hasegawa, M., Fujimoto, M. Matsushita, T., Horikawa, M., Takenaka, M., Ogawa, F., Sugama, J., Steeber, D. A., Sato, S., and Takehara, K. (2008). The loss of MCP-1 attenuates cutaneous ischemia-reperfusion injury in a mouse model of pressure ulcer. J. Invest. Dermatol. 128, 1838-1851.

Sammut, I. A., Foresti, R., Clark, J. E., Exon, D. J., Vesely, M. J., Sarathchandra, P., Green, C. J., and Motterlini, R. (1998). Carbon monoxide is a major contributor to the regulation of vascular tone in aortas expressing high levels of haeme oxygenase-1. Br. J. Pharmacol. 125, 1437-1444.

Sandouka, A., Balogun, E., Foresti, R., Mann, B. E., Johnson, T. R., Tayem, Y., Green, C. J., Fuller, B., and Motterlini, R. (2005). Carbon monoxide-releasing molecules (CO$\mathrm{RMs})$ modulate respiration in isolated mitochondria. Cell. Mol. Biol. (Noisy-le-grand) 51, 425-432.

Sandouka, A., Fuller, B. J., Mann, B. E., Green, C. J., Foresti, R., and Motterlini, R. (2006). Treatment with CORMs during cold storage improves renal function at reperfusion. Kidney Int. 69, 239-247.

Sass, G., Barikbin, R., and Tiegs, G. (2012). The multiple functions of heme oxygenase- 1 in the liver. $Z$. Gastroenterol. 50, 34-40.

Sawle, P., Foresti, R., Mann, B. E., Johnson, T. R., Green, C. J., and Motterlini, R. (2005). Carbon monoxide-releasing molecules (CO-RMs) attenuate the inflammatory response elicited by lipopolysaccharide in RAW264.7 murine macrophages. $\mathrm{Br}$. J. Pharmacol. 145, 800-810.

Scharstuhl, A., Mutsaers, H. A., Pennings, S. W., Szarek, W. A., Russel, F. G., and Wagener, F. A. (2009). Curcumin-induced fibroblast apoptosis and in vitro wound contraction are regulated by antioxidants and heme oxygenase: implications for scar formation. J. Cell. Mol. Med. 13, 712-725.

Schwer, C. I., Guerrero, A. M., Humar, M., Roesslein, M., Goebel, U., Stoll, P., Geiger, K. K., Pannen, B. H., Hoetzel, A., and Schmidt, R. (2008). Heme oxygenase-1 inhibits the proliferation of pancreatic stellate cells by repression of the extracellular signal-regulated kinase $1 / 2$ pathway. J. Pharmacol. Exp. Ther. 327, 863-871.

Schwer, C. I., Mutschler, M., Stoll, P., Goebel, U., Humar, M., Hoetzel, A., and Schmidt, R. (2010). Carbon monoxide releasing molecule2 inhibits pancreatic stellate cell proliferation by activating p38 mitogen-activated protein kinase/heme oxygenase-1 signaling. Mol. Pharmacol. 77, 660-669.

Schwertner, H. A., and Vitek, L. (2008). Gilbert syndrome, UGT1A1*28 allele, and cardiovascular disease risk: possible protective effects and therapeutic applications of bilirubin. Atherosclerosis 198, 1-11.

Seixas, E., Gozzelino, R., Chora, A., Ferreira, A., Silva, G., Larsen, R., Rebelo, S., Penido, C., Smith, N. R., Coutinho, A., and Soares, M. P. (2009). Heme oxygenase1 affords protection against noncerebral forms of severe malaria. Proc. Natl. Acad. Sci. U.S.A. 106, 15837-15842.

Seta, F., Bellner, L., Rezzani, R., Regan, R. F., Dunn, M. W., Abraham, N. G., Gronert, K., and LaniadoSchwartzman, M. (2006). Heme oxygenase- 2 is a critical determinant for execution of an acute inflammatory and reparative response. Am. J. Pathol. 169, 1612-1623.

Sidgwick, G. P., and Bayat, A. (2012). Extracellular matrix molecules 
implicated in hypertrophic and keloid scarring. J. Eur. Acad. Dermatol. Venereol. 26, 141-152.

Singer, A. J., and Clark, R. A. (1999). Cutaneous wound healing. N. Engl. J. Med. 341, 738-746.

Siow, R. C., Sato, H., and Mann, G. E. (1999). Heme oxygenase-carbon monoxide signalling pathway in atherosclerosis: anti-atherogenic actions of bilirubin and carbon monoxide? Cardiovasc. Res. 41, 385-394.

Soares, M. P., and Bach, F. H. (2007). Heme oxygenase-1 in organ transplantation. Front. Biosci. 12, 4932-4945.

Soares, M. P., Lin, Y., Anrather, J., Csizmadia, E., Takigami, K., Sato, K., Grey, S. T., Colvin, R. B., Choi, A. M., Poss, K. D., and Bach, F. H. (1998). Expression of heme oxygenase-1 can determine cardiac xenograft survival. Nat. Med. 4, 1073-1077.

Srisook, K., Han, S. S., Choi, H. S., Li, M. H., Ueda, H., Kim, C., and Cha, Y. N. (2006). CO from enhanced $\mathrm{HO}$ activity or from CORM-2 inhibits both O2- and NO production and downregulates HO-1 expression in LPS-stimulated macrophages. Biochem. Pharmacol. 71, 307-318.

Steiling, H., Munz, B., Werner, S., and Brauchle, M. (1999). Different types of ROS-scavenging enzymes are expressed during cutaneous wound repair. Exp. Cell Res. 247, 484-494.

Stocker, R., Yamamoto, Y., Mcdonagh, A. F., Glazer, A. N., and Ames, B. N. (1987). Bilirubin is an antioxidant of possible physiological importance. Science 235, 1043-1046.

Tabibiazar, R., Cheung, L., Han, J., Swanson, J., Beilhack, A., An, A., Dadras, S. S., Rockson, N., Joshi, S., Wagner, R., and Rockson, S. G. (2006). Inflammatory manifestations of experimental lymphatic insufficiency. PLoS Med. 3, e254. doi:10.1371/journal.pmed.0030254

Takahashi, T., Shimizu, H., Morimatsu, H., Inoue, K., Akagi, R., Morita, K., and Sassa, S. (2007). Heme oxygenase-1: a fundamental guardian against oxidative tissue injuries in acute inflammation. Mini Rev. Med. Chem. 7, 745-753.

Takahashi, T., Shimizu, H., Morimatsu, H., Maeshima, K., Inoue, K., Akagi, R., Matsumi, M., Katayama, H., and Morita, K. (2009). Heme oxygenase1 is an essential cytoprotective component in oxidative tissue injury induced by hemorrhagic shock. J. Clin. Biochem. Nutr. 44, 28-40.

Tenhunen, R., Marver, H. S., and Schmid, R. (1968). The enzymatic conversion of heme to bilirubin by microsomal heme oxygenase. Proc. Natl. Acad. Sci. U.S.A. 61, 748-755.

Tenhunen, R., and Mustajoki, P. (1998). Acute porphyria: treatment with heme. Semin. Liver Dis. 18, 53-55.

Theodorakis, N. G., Zand, D. J., Kotzbauer, P. T., Williams, G. T., and Morimoto, R. I. (1989). Hemininduced transcriptional activation of the HSP70 gene during erythroid maturation in K562 cells is due to a heat shock factor-mediated stress response. Mol. Cell. Biol. 9, 3166-3173.

Tolosano, E., Fagoonee, S., Hirsch, E., Berger, F. G., Baumann, H., Silengo, L., and Altruda, F. (2002). Enhanced splenomegaly and severe liver inflammation in haptoglobin/hemopexin double-null mice after acute hemolysis. Blood 100, 4201-4208.

True, A. L., Olive, M., Boehm, M., San, H., Westrick, R. J., Raghavachari, N., Xu, X., Lynn, E. G., Sack, M. N., Munson, P. J., Gladwin, M. T., and Nabel, E. G. (2007). Heme oxygenase-1 deficiency accelerates formation of arterial thrombosis through oxidative damage to the endothelium, which is rescued by inhaled carbon monoxide. Circ. Res. 101, 893-901.

Tsimikas, S., and Miller, Y. I. (2011). Oxidative modification of lipoproteins: mechanisms, role in inflammation and potential clinical applications in cardiovascular disease. Curr. Pharm. Des. 17, 27-37.

Tzima, S., Victoratos, P., Kranidioti, K., Alexiou, M., and Kollias, G. (2009). Myeloid heme oxygenase-1 regulates innate immunity and autoimmunity by modulating IFN-beta production. J. Exp. Med. 206, 1167-1179.

Vachharajani, T. J., Work, J., Issekutz, A. C., and Granger, D. N. (2000). Heme oxygenase modulates selectin expression in different regional vascular beds. Am. J. Physiol. Heart Circ. Physiol. 278, H1613-1617.

Valenzuela, N. M., and Reed, E. F. (2011). The link between major histocompatibility complex antibodies and cell proliferation. Transplant. Rev. (Orlando) 25, 154-166.

van der Veer, W. M., Bloemen, M. C., Ulrich, M. M., Molema, G., Van Zuijlen, P. P., Middelkoop, E., and Niessen, F. B. (2009). Potential cellular and molecular causes of hypertrophic scar formation. Burns 35, 15-29.

Vera, T., Henegar, J. R., Drummond, H. A., Rimoldi, J. M., and Stec, D. E. (2005). Protective effect of carbon monoxide-releasing compounds in ischemia-induced acute renal failure. J. Am. Soc. Nephrol. 16, 950-958.

Vijayan, V., Baumgart-Vogt, E., Naidu, S., Qian, G., and Immenschuh, S. (2011). Bruton's tyrosine kinase is required for TLR-dependent heme oxygenase-1 gene activation via $\mathrm{Nrf} 2$ in macrophages. J. Immunol. 187, 817-827.

Vijayan, V., Mueller, S., Baumgart-Vogt, E., and Immenschuh, S. (2010) Heme oxygenase-1 as a therapeutic target in inflammatory disorders of the gastrointestinal tract. World J. Gastroenterol. 16, 3112-3119.

Wagener, F. A., Abraham, N. G., Van, K. Y., De, W. T., and Figdor, C. G. (2001a). Heme-induced cell adhesion in the pathogenesis of sickle-cell disease and inflammation. Trends Pharmacol. Sci. 22, 52-54.

Wagener, F. A., Eggert, A., Boerman, O. C., Oyen, W. J., Verhofstad, A., Abraham, N. G., Adema, G., Van, K. Y., De, W. T., and Figdor, C. G. (2001b). Heme is a potent inducer of inflammation in mice and is counteracted by heme oxygenase. Blood 98, 1802-1811.

Wagener, F. A., Da Silva, J. L., Farley, T. De, W. T., Kappas, A., and Abraham, N. G. (1999). Differential effects of heme oxygenase isoforms on heme mediation of endothelial intracellular adhesion molecule 1 expression. J. Pharmacol. Exp. Ther. 291, 416-423.

Wagener, F. A., Feldman, E., De, W. T., and Abraham, N. G. (1997). Heme induces the expression of adhesion molecules ICAM-1, VCAM-1, and E selectin in vascular endothelial cells. Proc. Soc. Exp. Biol. Med. 216, 456-463.

Wagener, F. A., Scharstuhl, A., Tyrrell, R. M., Von Den Hoff, J. W., Jozkowicz, A., Dulak, J., Russel, F. G., and Kuijpers-Jagtman, A. M. (2010). The heme-heme oxygenase system in wound healing; implications for scar formation. Curr. Drug Targets 11, 1571-1585.

Wagener, F. A., Toonen, E. J., Wigman, L., Fransen, J., Creemers, M. C., Radstake, T. R., Coenen, M. J., Barrera, P., Van Riel, P. L., and Russel, F. G. (2008). HMOX1 promoter polymorphism modulates the relationship between disease activity and joint damage in rheumatoid arthritis. Arthritis Rheum. 58, 3388-3393.

Wagener, F. A., Van Beurden, H. E., Von Den Hoff, J. W., Adema, G. J., and Figdor, C. G. (2003a). The hemeheme oxygenase system: a molecular switch in wound healing. Blood 102, 521-528.
Wagener, F. A., Volk, H. D., Willis, D., Abraham, N. G., Soares, M. P., Adema, G. J., and Figdor, C. G. (2003b). Different faces of the heme-heme oxygenase system in inflammation. Pharmacol. Rev. 55 , 551-571.

Wang, G., Hamid, T., Keith, R. J., Zhou, G., Partridge, C. R., Xiang, X., Kingery, J. R., Lewis, R. K., Li, Q., Rokosh, D. G., Ford, R., Spinale, F. G., Riggs, D. W., Srivastava, S., Bhatnagar, A., Bolli, R., and Prabhu, S. D. (2010). Cardioprotective and antiapoptotic effects of heme oxygenase1 in the failing heart. Circulation 121, 1912-1925.

Wang, N., Wang, G., Hao, J., Ma, J., Wang, Y., Jiang, X., and Jiang, H. (2012). Curcumin ameliorates hydrogen peroxide-induced epithelial barrier disruption by upregulating heme oxygenase- 1 expression in human intestinal epithelial cells. Dig. Dis. Sci. doi: 10.1007/s10620012-2094-7. [Epub ahead of print].

Wang, X., Wang, Y., Kim, H. P., Nakahira, K., Ryter, S. W., and Choi, A. M. (2007). Carbon monoxide protects against hyperoxiainduced endothelial cell apoptosis by inhibiting reactive oxygen species formation. J. Biol. Chem. 282, 1718-1726.

Wei, Y., Chen, P., De Bruyn, M., Zhang, W., Bremer, E., and Helfrich, W. (2010). Carbon monoxide-releasing molecule-2 (CORM-2) attenuates acute hepatic ischemia reperfusion injury in rats. BMC Gastroenterol. 10, 42. doi:10.1186/1471-230X-10-42

Wijayanti, N., Kietzmann, T., and Immenschuh, S. (2005). Heme oxygenase-1 gene activation by the $\mathrm{NAD}(\mathrm{P}) \mathrm{H}$ oxidase inhibitor 4-(2aminoethyl) benzenesulfonyl fluoride via a protein kinase $B, p 38$ dependent signaling pathway in monocytes. J. Biol. Chem. 280, 21820-21829.

Willis, D., Moore, A. R., Frederick, R., and Willoughby, D. A. (1996). Heme oxygenase: a novel target for the modulation of the inflammatory response. Nat. Med. 2, 87-90.

Willoughby, D. A., Moore, A. R., Colville-Nash, P. R., and Gilroy, D. (2000). Resolution of inflammation. Int. J. Immunopharmacol. 22, 1131-1135.

Winburn, I. C., Gunatunga, K., Mckernan, R. D., Walker, R. J., Sammut, I. A., and Harrison, J. C. (2012). Cell damage following carbon monoxide releasing molecule exposure: implications 
for therapeutic applications. Basic Clin. Pharmacol. Toxicol. doi: 10.1111/j.1742-7843.2012.00856.x. [Epub ahead of print].

Witt, H., Apte, M. V., Keim, V., and Wilson, J. S. (2007). Chronic pancreatitis: challenges and advances in pathogenesis, genetics, diagnosis, and therapy. Gastroenterology 132, 1557-1573.

Wu, B. J., Kathir, K., Witting, P. K., Beck, K., Choy, K., Li, C., Croft, K. D., Mori, T. A., Tanous, D., Adams, M. R., Lau, A. K., and Stocker, R. (2006). Antioxidants protect from atherosclerosis by a heme oxygenase1 pathway that is independent of free radical scavenging. J. Exp. Med. 203, 1117-1127.

Wynn, T. A. (2008). Cellular and molecular mechanisms of fibrosis. J. Pathol. 214, 199-210.
Yachie, A., Niida, Y., Wada, T., Igarashi, N., Kaneda, H., Toma, T., Ohta, K., Kasahara, Y., and Koizumi, S. (1999). Oxidative stress causes enhanced endothelial cell injury in human heme oxygenase-1 deficiency. J. Clin. Invest. 103, 129-135.

Yin, W., Zhang, X., Shi, X., and Li, Y. (2012). Curcumin protects SHSY5Y cells from oxidative stress by up-regulating HO-1 via Phosphatidylinositol 3 Kinase/Akt/Nrf-2 and down-regulating $\mathrm{HO}-2$. Mol Neurodegener 7(Suppl. 1), S14.

Zhou, J. L., Li, G., Hai, Y., Guan, L., Huang, X. L., and Sun, P. (2009). Protection of carbon monoxidereleasing molecule against lung injury induced by limb ischemiareperfusion. Chin. J. Traumatol. 12, 71-76.
Zhu, Z., Wilson, A. T., Mathahs, M. M., Wen, F., Brown, K. E., Luxon, B. A., and Schmidt, W. N. (2008) Heme oxygenase-1 suppresses hepatitis $\mathrm{C}$ virus replication and increases resistance of hepatocytes to oxidant injury. Hepatology 48, 1430-1439.

Zobi, F., Degonda, A., Schaub, M. C., and Bogdanova, A. Y. (2010). $\mathrm{CO}$ releasing properties and cytoprotective effect of cis-trans$[\mathrm{Re}(\mathrm{II})(\mathrm{CO}) 2 \mathrm{Br} 2 \mathrm{~L} 2] \mathrm{n}$ complexes. Inorg. Chem. 49, 7313-7322.

Conflict of Interest Statement: The authors declare that the research was conducted in the absence of any commercial or financial relationships that could be construed as a potential conflict of interest.
Received: 01 February 2012; paper pending published: 27 February 2012; accepted: 13 April 2012; published online: 07 May 2012.

Citation: Lundvig DMS, Immenschuh $S$ and Wagener FADTG (2012) Heme oxygenase, inflammation, and fibrosis: the good, the bad, and the ugly? Front. Pharmacol. 3:81. doi: 10.3389/fphar.2012.00081

This article was submitted to Frontiers in Drug Metabolism and Transport, a specialty of Frontiers in Pharmacology.

Copyright (c) 2012 Lundvig, Immenschuh and Wagener. This is an openaccess article distributed under the terms of the Creative Commons Attribution Non Commercial License, which permits non-commercial use, distribution, and reproduction in other forums, provided the original authors and source are credited. 